\title{
Slaughterbench of Humanisms: The 1987 Heidegger Affair in Intellectual-Historical Perspective
}

\section{Stefanos Geroulanos}

In the fall of 1987, one of the most significant affairs in recent intellectual history erupted in France when the unknown Chilean writer Victor Farias published a well-researched but philosophically unimpressive book on Martin Heidegger's Nazism. To publishers abroad, notably in Germany, the volume rang a hollow bell, and remained unprinted, as debates on existentialism, Heidegger's engagement with the Nazi party, and his continuing political position in the fifties lay in the past. ${ }^{1}$ But in France, despite a certain academic awareness of Heidegger's Nazi engagement, the effect was very different: ${ }^{2}$ Farias struck a nerve, and suddenly the intellectual milieu erupted into furious polemics. This 1987 Heidegger Affair has long been read as the final curtain for a movement that lent support to several epistemological ruptures in French philosophy (according to some of the more positive accounts) or flourished as an uncritical and pretentious audience for Heidegger (in the less generous ones). Yet although it provided a number of signs indicating shifts in intellectual tendencies, the affair has never been seriously treated as a barometer for the recent past of French thought. ${ }^{3}$ The present essay attempts to offer a necessarily schematic intellectualhistorical description of the 1987 affair as an intellectual event emerging with the rise of a neo-humanist politics that came with the "French Philosophy of the Eighties," concentrating on its treatment of a politicophilosophical legacy whose importance and political ambiguities continue to the present day. ${ }^{4}$ 


\section{SLAUGHTERBENCH OF HUMANISMS}

Following Heidegger's death in 1976, as well as the death of his prime French “angel” Jean Beaufret in 1982, the master's thought became officially consecrated in France as one of the main pillars of "French" philosophy in the twentieth century. ${ }^{5}$ Work on Heidegger expanded during the 1980s: studies of his work both increased numerically and defined fields (e.g. comparative literature) that it had so far not broadly penetrated. French high-school students read Heidegger for the baccalauréat philosophy examination. ${ }^{6}$ But at the same time, orthodox Heideggerianism took a downward turn, losing its centrality among possible interpretations of Heidegger and of the history of philosophy. For a long time, close Heideggerians such as Beaufret, François Fédier, Dominique Janicaud, François Vezin, Emmanuel Martineau, Jean-Michel Palmier, and Frederic de Towarnicki had formed a significant philosophical avant-garde, influencing "every philosopher from... Cornelius Castoriadis to Michel Foucault,"7 and participating in movements from deconstruction to Bourdieu's sociology. Yet by the time of Beaufret's death in 1982-indeed since much earlier - the novelty of their work had waned, and defections to other philosophical camps were building up. Orthodox Heideggerianism incorporated none of the substantive philosophical "innovations" since the 1960s, not even those by philosophers deeply influenced by Heidegger - Michel Foucault, Emmanuel Levinas, Jacques Derrida, late Marxism (Jean-François Lyotard, Kostas Axelos, et al), or the nouveaux philosophes. Orthodox Heideggerianism also evaded political challenges that the intellectual realm became much involved in-from the end of French colonialism to May ' 68 and the 1980s turn toward liberal humanism - instead maintaining its appropriately anti-political character. As a result, the fading of the orthodox group was not seriously noticed until the famous political controversy ignited by Farias' livre-provocateur, Heidegger et le nazisme. ${ }^{8}$ The unprecedented immediacy of the 1987 debate should be understood, with regard to this decline in Heideggerian orthodoxy and the change in perceptions of humanism, as a battleground for the perception of the human rights discourse directed principally_but not solely_against communism and the intellectual left, and a precursor to recent debates about multiculturalism and religion.

\section{Decline and Fall of the Heideggerian Empire}

For France, the eighties were a period of debates regarding not only the legacy of Vichy but also the incorporation and subversion 


\section{STEFANOS GEROULANOS}

of the post-1945 non-democratic movements into the mainstream. The presidency of François Mitterand marked an end to an era, a major-alternatively the last - moment for the postwar left. His election brought in a different way of reading contemporary French history, one that was supported by the recent work of historians such as François Furet and that was no longer dependent on the political oppositions of the early Cold War and the end of the colonial era. ${ }^{9}$ It helped heal a society deeply divided between political left and right and partook more extensively than previous decades in a reconsideration of the century's political legacies. This makeover is evident in the intellectual and public tensions and squabbles over topics that to outsiders might seem trivial or outdated. In particular, the implication of individuals and groups with Nazism (coming with the ascent of the Front National) was a major cause of public debate, indeed one that matched in ferocity similar debates in Germany and Austria. ${ }^{10}$ In 1987, the Heidegger Affair was preceded by at least three major affairs concerning Nazism and the Vichy legacy. Their precedent fueled a remarkable (if, given the circumstances, not too surprising) fury in the French media over Heidegger and recent French philosophical politics. Though not all changes that the debate initiated in the public and philosophical realm became immediately noticeable, a confrontation between different camps of French thinkers produced a difficult and deeply tense moment that evidenced deep fractures in French thought.

Marked changes in the approach to Heidegger had taken place from much earlier. As already mentioned, Heidegger's thought and legacy had achieved a certain canonization by the mid-1970s. At the same time, this canonization gradually escaped the traditional control of French Heideggerians around Beaufret. One of the major events or instances of this canonization was the dedication of the 1983 Cabier de l'Herne to Heidegger. ${ }^{11}$ But unlike what one would expect, at the helm of the massive volume was not a Beaufret student or friend, but Michel Haar, who as a young philosopher in the mid-70s had expressed his dissatisfaction with Beaufret's translations and presentation of Heidegger. Haar had sent all this in a letter to Heidegger, ${ }^{12}$ a letter cosigned by, among others, Alain Renaut (who soon thereafter broke completely with Heideggerianism of any sort), Roger Munier (a personal friend of Heidegger's and early translator of his "Letter on Humanism"), and Henri Birault (one of Heidegger's most important early French readers, who had originally praised Beaufret unconditionally). ${ }^{13}$ Responding in public, Beaufret scoffed at the letter and indicated that 


\section{SLAUGHTERBENCH OF HUMANISMS}

Heidegger held its authors in no greater respect than he himself did. Yet this letter marked a first challenge to Beaufret's position of proximity to Heidegger and competence in vetting the quality and "propriety" of writings on him in France. A bibliography of French Heidegger studies in the Cabier demonstrated, for the first time, how few the publications of the orthodox group had been and even that Beaufret had published almost nothing on Heidegger during his 1950s heyday. Indeed, orthodox disciples produced none of the original work included in the Cabier. Another public tribute to Heidegger in Magazine Litteraire further rejected Beaufret's denunciations of the unorthodox, recognizing the significance of work by individuals outside his coterie. ${ }^{14}$ Participation by orthodox Heideggerians at colloquia by non-Heideggerians became negligible. For example, a March 1987 conference on Heidegger at the College International de Philosophie included work by such figures as Jacques Derrida, Emmanuel Levinas and Giorgio Agamben, and younger philosophers like Françoise Dastur, but none by thinkers close to Beaufret. $^{15}$

Such work was indicative of the turn the Heidegger legacy had taken, as "Heidegger" became better developed by strands of French phenomenological and post-phenomenological (but not strictly Heideggerian) thought. Heideggerians themselves experienced tensions after Beaufret's death. ${ }^{16}$ Even the posthumous publication of Beaufret's final Dialogue avec Heidegger IV offered no alternative to this decline: unlike the first three volumes, whose organization had been thematic, this volume included no unpublished texts or "pioneering" studies (the only unpublished text therein was anticipating publication in a volume on Lacan). The essays themselves were not of the level of Beaufret's earlier work, and suggested that he had largely run his course. Still worse, Beaufret's friends, though important, had never been that many. His 1950s feud with Wahl, whom Beaufret apparently blamed for blocking his doctorate - hence barring him from a university carreer (HF 1:176-81, 2:108) — culminated toward the end of his life in a bitter distance from French intellectual life, especially the intellectual left to which he had belonged in the 1940s. ${ }^{17}$ Disciples were hampered with these legacies, a point that had hurt their own reputation well before 1987.

\section{Representation}

Indeed, the only new orthodox Heideggerian contribution of significance was the full translation of Sein und Zeit, by now well 


\section{STEFANOS GEROULANOS}

over half a century late, directed by François Vezin. ${ }^{18}$ Vezin had been particularly close to Beaufret, who on behalf of Heidegger's family had "authorized" him in the late 1970s to translate Sein und Zeit in its entirety, following from the translation of Division I by Alphonse de Waelhens and Walter Boehm in 1964. ${ }^{19}$ Etre et Temps, which completed a translation contract over five years old (and a project over four decades old), erupted into a debate with a competing, "unauthorized" recent publication of the project by Emmanuel Martineau. ${ }^{20}$ Martineau, a normalien and faithful student of Beaufret, had undertaken the project on his own, probably after Beaufret's death. ${ }^{21}$ The attempt by Vezin and Beaufret's other protégé François Fédier, to proclaim this translation inferior to the "authorized" one met with little support. ${ }^{22}$ The debate concerned adequacy of terms - which had been important for the legitimacy of orthodox Heideggerians since the 1940s rejection of Corbin's translation of Dasein as réalité bumaine, and which had become a problem ever since the first critiques of their choices in the 60 s debate in Critique. ${ }^{23}$ Yet this time, "adequacy of terms" referred to the obfuscating translation slang that, according to critics, plagued Vezin's translation, and quickly brought a community of translators to crisis. Martineau boasted his translation as unauthorized, responding that Vezin's "horribly inadequate" German had led him to render Sein und Zeit in an intentionally obtuse fashion. ${ }^{24}$ The scorn poured on Vezin by other translators-Lacoue-Labarthe, Janicaud, Haar, and Roger Munier among them-was often even more biting. ${ }^{25}$ Vezin had one strong card to play and he played it well, concentrating on the fact that Beaufret (and, through him, the Heidegger family) had trusted him with the translation: his master had known better. But the turn to Heidegger and Beaufret themselves did not work, precisely because detractors were better placed institutionally, and also because few people outside a rather small circle cared much for the translations. Leaving a public "to judge," the conflict further lessened the image of Heideggerianism to a culture of self-congratulatory denunciation. A similar clash followed the 1984 publication of Questions II when François Châtelet, who in the 60s had participated favorably in discussions on the relationship between Heidegger and Marx, published a strongly-worded negative review. ${ }^{26}$ Châtelet blamed translators for an anachronistic ordeal, waxing lyrically about the 1955 Cérisy conference on Heidegger and the openness of 1950 s Heideggerianism. ${ }^{27}$ From the perspective of phenomenology, Châtelet wasn't altogether unfair: during the 1950s, the study of Heidegger was associated with Beaufret on the one hand, 


\section{SLAUGHTERBENCH OF HUMANISMS}

but also with less orthodox and better established readers (and critics) like Jean Wahl and especially Jean Hyppolite, not to mention others like Levinas.

Moreover, thought influenced "second-hand" by Heidegger (and thought influenced in a less orthodox fashion by Heidegger, e.g. as studied under Wahl or Hyppolite) started renouncing its respect for the Heideggerian utopias and pedestals. Jacques Derrida, who had long expressed significant distances from Heidegger, ${ }^{28}$ and whose Heidegger depended as much on a reading of Husserl as on a reading of Levinas, offered a major critique in 1983, when he lectured on sexual and ontological difference. ${ }^{29}$ Taking up the problem of the non-distinction between the sexes in Heidegger's Dasein, Derrida indicted Heidegger for failing to address the difference between the sexes as ontological, ${ }^{30}$ thus leveling basic distinctions in a manner that contributed to the gender hierarchization of Being. Dasein was insufficient in thinking difference between separate subjects, and reduced such subjects to a single model; for Derrida, it required at least "considerable adjustments." Derrida's critique of Dasein (which in one sense at least pushes toward a division that is at least as radical (if not considerably more so) than his earlier critiques of finitude and historicity) parallels the path that French phenomenological and post-phenomenological thought had taken, taking over and moving past Heidegger's anti-subjectivism. After thirty years of philosophical questionings of the unity and dependences of the subject by thinkers like Derrida, Lyotard, Foucault and Levinas, Heidegger's position was surpassed. In this context, an elaboration of differences Derrida saw as inherent in ontology (and whose anthropologization by Heidegger he found insufficient, if ontology was to retain any sort of primordial status) was necessary as reaching the root of Heidegger's Dasein altogether.

Other concrete philosophical distantiations by Heidegger's children had begun from the mid 1960s, most notably in the work of Pierre Bourdieu and Emmanuel Levinas. It is difficult to trace the origins of the critique of Heideggerian thought, because it can be read as stemming from several categories: works not influenced by Heidegger; works who disagree with his most basic tenets; works influenced by but rejecting Heidegger; and so on. Nevertheless, we can today point to certain texts that initiated the undermining of the French Heideggerian reading of Heidegger and perhaps the rejection of much of his thought. In 1975, Bourdieu published a long article, "L'Ontologie Politique de Martin Heidegger," in one of the first issues of his journal 


\section{STEFANOS GEROULANOS}

Actes de la Recherche en Sciences Sociales. ${ }^{31}$ In it, he used Heidegger-inspired discursive analysis without granting immunity from such analyses to Heidegger himself. Bourdieu carefully located Heidegger in a conservative discourse where conservative academics "provided an objectification which echoed his own politico-moral views." 32 The political analysis shows clear connections to Karl Löwith's 1946 "The Political Implications of Heidegger's Existentialism," ${ }^{33}$ not least in its attempt to situate Heidegger's work in his political-intellectual environment, but Bourdieu's theoretical framework was heavily influenced by recent developments, like Foucault's discursive analysis and Jean-Pierre Faye's Langages Totalitaires. Bourdieu opposed granting the status of pure, socially unaffected approaches to philosophy, and the sanitized Heidegger of the French 1960s provided him with an ideal case for a critique that would explain the distinction and connections between the "internal" (lexical and argumentative) and "external" (discursive, historical, political) aspects of a text. ${ }^{34}$

In a different realm, Levinas' well-known work had from the late 1940s on highlighted and challenged the ethical inadequacy of Heidegger's allegedly pure ontology. ${ }^{35}$ Levinas saw Heidegger as essential to contemporary thought and repeatedly affirmed his own dependence on him. ${ }^{36}$ Yet his objections to Heidegger were not merely numerous and significant, they spanned his entire oeuvre, from the 1935 "De l'evasion" through the ily a motif he developed in the 1940s and his turn toward an otherwise than being in the 1960s. ${ }^{37}$ Levinas insisted on irreducible boundaries between subjects, striking a blow at the "universally-shared" subjectivity of Dasein. Subjects do not flow into each other, as the latter would suggest, and hence Being is exteriority insofar as it denotes this separation and contrast (TI 290): one has to move beyond the brute factuality of Being (OE 54-5) for an ethical relation to occur (TI 301-2). Levinas further rejected the institutionalization of Heideggerian antihumanism in the human sciences (Foucault), seeing antihumanism as tantamount to a reduction of identity to equality, and as constitutive of a self-difference that served the dispersal and self-distancing of the subject. ${ }^{38}$ Without an ethical understanding of the Other through a face-to-face relation, Being was condemned to incompleteness and permeated by barbarity (TI 291, OE 73). Retaining certain basics of Heideggerian Dasein, Levinas came to a new philosophical foundation, expressing both a revulsion toward Heidegger's postwar silence and a distrust of his mystification of Being. ${ }^{39}$ Every contemporary thinker, he noted, owes to Heidegger "a debt one 


\section{SLAUGHTERBENCH OF HUMANISMS}

often regrets." ${ }^{40}$ The significance of Levinas was such for readers like Jean-Luc Marion, Jean-Luc Nancy and Jacques Derrida as to completely re-shape the Heidegger legacy and push away from the primacy of ontology.

What these changes meant is that the Heideggerian metaGreek Elysian Fields of philosophical exchange-which claimed philosophical authenticity for itself and was echoed in French heroic philoclassicism ${ }^{41}$ (which even Derrida had been charged with abiding by $^{42}$ ) — was no longer sustainable. In the famous 1960s seminars at René Char's home, Heidegger and his interlocutors had adopted Provence as the echo of Classical Greece:

Here by the olive trees, which cling to the slope before us, all the way down into the plain where, in the distance and not yet visible, the Rhône flows, we start again... Behind us lies the Delphic mountain massif... Whoever finds his way there, is a guest of the Gods.43

To a considerable degree, the self-fashioning of orthodoxy depended on such a Meta-Greece. As some offspring of orthodox Heideggerianism began to move away from their earlier loyalty, so began the criticism of such pedestals of orthodoxy. Trust in such a MetaGreece qua home of pure philosophical exchange declined as the thinking of democracy by prominent leftists like Castoriadis, Claude Lefort and Pierre Vidal-Naquet came to demand a re-situating of the debt to classical Greece. ${ }^{44}$ Most prominently, Lacoue-Labarthe published in 1981 an essay on Heidegger's Rectoral Address that proceeded to dismantle Meta-Greece, driving parallels between it and Heidegger's Rectorate. ${ }^{45}$ As Heidegger's vision started to look like a pinnacle of anti-modernism that failed to address contemporary philosophicopolitical issues, his overall thought became more suspect. ${ }^{46}$

In the eighties there arose much more hostile strands of antiHeideggerianism, notably in the writings of Luc Ferry and Alain Renaut, following from the 1970s movement of the Nouveaux Philosophes. The new philosophers' vogue, oft-discussed and even well-documented on television, combined with a general move away from the radicalism of the early 70s and a new rise of liberalism and a language of rights. To a substantial degree, the new philosophers also transformed the very contours and possibilities of the intellectual public, at once reaching for a less-philosophically-educated audience and relating much more comfortably to the mass media (Bernard-Henri Lévy is a famous example). Yet the "new philosophers" did not target Heidegger and 


\section{STEFANOS GEROULANOS}

his disciples: André Glucksmann's Master Thinkers treated Heidegger as a pillar against contemporary radicalisms, ${ }^{47}$ while Lévy's Grasset collection Figures published a collection of essays on Heidegger and religion. ${ }^{48}$

The new philosophers' work was echoed across the political spectrum and heralded a humanistic renaissance. During the previous three decades, and largely in opposition to the French Communist Party, left antihumanism had developed a dual critique of political humanism and philosophical anthropocentrism as being tainted by the very same battling ideologies that incessantly claimed and disgraced humanism for their own causes. "Antihumanism" (a term mostly used by its critics and pejoratively) largely claimed itself to be a deeper sort of humanism that was opposed to humanisms, that decentered "man" and thus returned to man his fundamental dignity. Its claim was, especially if we are to follow Jacques Derrida's reading in "The Ends of Man," to a deeper humanism unburdened by political problematics and the violence of ideals. ${ }^{49}$ Antihumanism was heavily influenced by Heidegger's Letter on Humanism, Alexandre Kojeve's reading of Hegel, Merleau-Ponty's Humanism and Terror (and their failure) and Foucault's reading of the human sciences, and was politically consistent with a distinguishing of France and its culture from the crushing pincers of America and the USSR (a traditional German romantic theme famously evoked by Heidegger with regard to Nazi Germany during the 1930s, later invoked in France by Kojeve and de Gaulle). ${ }^{50}$ With structuralism's displacement of the human subject and its value in domains of signification, antihumanism completed its transformation into epistemology ${ }^{51}$ — that is, until the late 1970s finally succeeded in wresting conceptions of humanism away from the PCF's claim to a humanism of universal equality. Alexander Solzhenitsyn's Gulag Archipelago, ${ }^{52}$ François Furet's disillusioning work on the French Revolution, ${ }^{53}$ and Castoriadis and Lefort's work on autonomy, philosophically supported novel readings of the human condition, to a degree claiming for this condition a less tension-ridden definition of modernity than recent intellectual predecessors would agree to. The rhetoric of human rights that then developed in the 1980s reduced antihumanism to simple contempt for human life, while the nascent presidency of François Mitterand more or less ended the left's search for alternative politics. ${ }^{54}$

The 1980s French neohumanists' prime concern was a latterday "defense" of liberal democracy and the legacy of the Enlightenment as these developed in the $19^{\text {th }}$ century. This revival was carried out largely on 


\section{SLAUGHTERBENCH OF HUMANISMS}

the claim of an ethical/political necessity, a "necessity" that was in many ways radically opposed to the "necessity" permeating the ethical/political thought of Levinas and deconstruction. ${ }^{55}$ This discourse of human rights took as its basis certain tropes of a "weight" and "content" of man, ${ }^{56}$ not defining itself strictly as a politics but as a suprapolitical intervention ${ }^{57}$ relying on Montesquieu (rather than Voltaire or Diderot), primarily treating his work as a constructive juridicopolitical cradle for modernity. ${ }^{58}$ The effort of French "neohumanists" continued into the 1990s to treat subjectivity on grounds associated with the Enlightenment so as to "avert" a "narcissistic individualism" that arrived with the 1960s. ${ }^{59}$ And as much of the radical left and its aspirations were already discredited (largely by the noweaux philosophes, with whom the neohumanists had an ambivalent relationship), the attack against 1960s' antihumanism came to undermine the philosophico-political legitimacy of (among others) the Heideggerian project, notably in the work of Ferry and Renaut.

Ferry and Renaut's 1984 book on contemporary antihumanism centered specifically on French philosophers indebted to Heideggerwhom it treated as bound to his thought and unoriginal on their own account. ${ }^{60}$ Renaut was a disgruntled former student of Beaufret and had already rejected him by signing the aforementioned letter to Heidegger that saw Beaufret as an obtuse misreader. By 1984, his loyalties had switched camp altogether. He wrote La Pensée 68 with Luc Ferry, later a Minister of Education (2002-2004). The two political theorists would explain Pensée 68 by noting that "[as] Marxism had already become a dead ideology, we aimed to deconstruct the French variants of Heideggerianism," (HM 9), whose antisubjectivism they saw as a real danger to cultivated democracy. ${ }^{61}$ Finding in the culture of Heidegger none of the anti-technological-establishment-radicalism that had so intrigued past readers, the authors rejected his "disciples" Foucault, Bourdieu, Derrida and Lacan-ignoring more "obvious" targets like Beaufret - as anti-modern and anti-democratic. La Pensee " 68 polemically charged that the Heideggerian "cult of paradox" and "rejection of clarity" provided the grounds for a cover-up of contradictions inherent in 1960 s philosophical projects. ${ }^{62}$ And in doing so, the volume labeled suspicious anything characterized by anti-positivism, linguistic obliqueness, anti-subjectivism and especially the Heideggerian attempt to overcome the reduction of Being to presence. ${ }^{63}$ In early 1987, Ferry and Renaut followed the success of Pensée 68 with 68-86: Itineraires de l'Individu. ${ }^{64}$ 


\section{STEFANOS GEROULANOS}

Moreover, Ferry and Renaut were not the only ones insisting on a new approach to philosophy and its political effects. Gilles Lipovetsky's L'Ere du vide constituted a rejection of May ' 68 for its "individualism" - as a politicophilosophical twist that should no longer be taken seriously lest France degenerate into this very individualism. ${ }^{65}$ André Glucksmann's 1987 Descartes, c'est la France, ${ }^{66}$ as its own title suggests, read Descartes as synonymous with French modernity, and argued that contemporary philosophical life was unthinkable without him. Times were changing: even the radicalism of the seemingly unpolitical was shifting to the margins of an intellectual playing field.

At the same time, Heidegger's politics was being repeatedly invoked as more dubious than once thought. In the 1983 Cabier de l'Herne Jean-Michel Palmier, a conservative Germanist and longtime Heidegger supporter, reported a comment by Heidegger to Jünger, that he [Heidegger] would not apologize for his Nazism until Hitler rose from the grave to apologize to him. ${ }^{67}$ In 1986, Löwith's account of his meeting with Heidegger in Rome (when Heidegger spoke to him of the importance of historicity in his engagement with the Nazis) appeared in German and quickly reached France, raising the credibility of Löwith's 1946 interpretation. ${ }^{68}$ Later used consistently to both support and disprove the Farias line of argument, ${ }^{69}$ the memoir joined other phenomenologically-oriented readings of Heidegger's troubled politics. Philippe Lacoue-Labarthe published two essays on Heidegger's politics in his 1986 Imitations des Modernes: Typographies II, in which he made no secret of his debt and strong opposition to the master. ${ }^{70}$ LacoueLabarthe rejected Heidegger's search for origins as politically problematic and his contempt for imitation as characteristic of cultural conservatism. All these texts signaled change: "Eclipse or decline? Difficult to say..." lamented Palmier in $1986 .^{71}$

\section{Nineteen Eighty-Seven}

1987 brought home the implications and importance of the gradual intellectual shifts regarding Heidegger, most forcefully through the Heidegger debate that started with the publication of Victor Farias' Heidegger et le Nazisme. Notwithstanding the debate, the year was a prolific one for Heidegger studies, as France witnessed the publication of at least 15 books on him even before publishers took up the Farias effect. ${ }^{72}$ Significantly, the Heidegger Affair was neither the only nor the most important debate of the year concerning the memory and horrors of 


\section{SLAUGHTERBENCH OF HUMANISMS}

National Socialism, but only one of three major controversies, together with the excruciating Klaus Barbie trial (which ended in July with the conviction of the "Butcher of Lyon" for crimes against humanity), and the famous and continuing debate over Claude Lanzmann's Shoah. As if these large debates were not enough, the publications of Mircea Eliade's unrepentant memoirs, Paul de Man's collaborationist writings, and Beaufret's letters of support to the notorious Holocaust revisionist Robert Faurisson alarmed sentiment against positions that could be seen as turning a blind eye to fascism. In this context, the knee-jerk, neurotic character of the fury that encompassed print media (even television ${ }^{73}$ ) over Heidegger is remarkable but unsurprising. ${ }^{74}$ Previous debates combined well with the intellectual tendency to loudly denounce those assenting to the unacceptable and this time, la trabison des clercs seemed all-inclusive. Thus, an affair that would normally be contained in academic circles had students quitting courses upon hearing "Heidegger" "75 and newspapers writing "Being is hitleric. It's Time that this was demonstrated."76

"Heil Heidegger?" cried Libération in a two-paged article on October 16. The announcement carried a large rendition of the nowfamous portrait of Heidegger bearing the Hitler moustache and Nazi insignia on his lapel, as well as an image of him in a meeting of "Rectors for German Science." ${ }^{\text {77 }}$ Noting that Victor Farias' Heidegger et le Nazisme showed "conclusively" the extent of Heidegger's Nazism, the article set the tone for much of the early debate by asking "is it possible to remain a Heideggerian?" 78 Announced a month earlier by its preface's author, former nowveau-philosophe Christian Jambet ${ }^{79}$ the well-anticipated appearance of the volume in mid-October sparked off a series of articles and essays, the majority of which indicted not only Heidegger but more or less anyone attached to his thought as intellectually dangerous. Even Roger-Pol Droit's sober review in Le Monde, which preceded the article in Liberation, argued that it was perhaps impossible to continue working on Heidegger along past lines. ${ }^{80}$ The question was not new, but as a problem it had seemed secondary after Beaufret and Axelos' 1960s championing of Heidegger as the philosopher resolutely fighting against both grand and quotidian totalitarianisms in search of a philosopher's utopia. As is well known, the critique of subjectivity had served as a ground for Foucault's historical epistemology in the first part of L'archeologie du savoir, Derrida's deconstruction, and even the New Left imagination tied to the 1957-62 journal Arguments (a thinking that survived the journal). ${ }^{81}$ Louis Althusser's references to 
the Holiwege pointed in the same direction. ${ }^{82}$ The French New Left, which built on the Hegelian Marxism pioneered by Jean Hyppolite, Eric Weil, Alexandre Kojève, and others, was perhaps the most widely (and, in general, least dogmatically) accepted of Heidegger's French children during the 1960s - though it no longer formed a major philosophical tendency and was largely ignored in the affair. ${ }^{83}$

With Farias, the question suddenly changed: if Heidegger had been an extreme, unrepentant Nazi, how could one overlook the totalitarian undertones that could be found in his work? What was this remnant of the sixties, the gauche heideggerienne, if not an absurdity? Did not Heidegger's restructuring of subjectivity and his anti-humanist existentialism hide a contempt for man and society similar to that of the Nazis? Farias showed, relying on East Berlin archives but also on Guido Schneeberger's 1961 Nachlese zu Heideggerand Hugo Ott's recent research, that Heidegger had not just been erratically involved with the Nazis during the Rectorate (VF 16). Farias proceeded to argue that Heidegger was not just a tainted philosopher but a theorist of the Sturm Abteilung, the Nazi brownshirts ${ }^{84}$ As this theory "explained" Heidegger's own note that he had completely broken with the Nazi elite after June 1934 (as June 30" ${ }^{\text {th }}$, 1934, the "Night of Long Knives" marked the obliteration of the SA), ${ }^{85}$ it found the German thinker committed to a thuggish fascism from his early writings until his death (VF 202-8, FHW 278). Had the treatment of Heidegger's political past by his partisans been less tendentious, Farias' book would have at best ended on the shelves of libraries. ${ }^{86}$ His interpretation was problematic, refusing to read the philosophical dimension to Heidegger's works and resting on arguments that any competent interpreters of Heidegger have seen as laughable. Notoriously, Farias blew out of context and proportion two tributes that Heidegger had paid in the beginning and end of his public life to the virulently Anti-Semitic eighteenth-century monk Abraham à Santa Clara, celebrated by Heidegger's mother city Meßkirsch. ${ }^{87}$ Farias ignored Heidegger's ostensible unwillingness to echo Abraham's Anti-Semitism (in 1987 there were virtually no signs of Heidegger's own 1930s Anti-Semitism) and also ignored the context of Heidegger's texts-Heidegger wrote the first one in seminary at the age of eighteen - and spent three times more space on these texts than on Sein und Zeit. ${ }^{88}$ The ensuing interpretation of Abraham as a cornerstone in Heidegger's thought flowed rather too easily.

What was widely accepted was Farias' research, which rendered the Beaufretian defense (that Heidegger had been an occasional Nazi 


\section{SLAUGHTERBENCH OF HUMANISMS}

in 1933-4, had quickly realized his error and had rejected it) unsustainable, and even pro-Nazi. In the media event, "Heidegger" turned into a signifier of evil, an influence whose attraction hid dangers of a Faustian deal with Nazism. This was, in part, a consequence of sources cited by Farias that, though long in publication, remained outside mainstream attention. A more serious reception of Schneeberger's Nachlese zu Heidegger would have alleviated most of the shock, but it remained untranslated and had even been rejected in Critique by François Fédier as "malignant" during the heyday of Heideggerian orthodoxy. ${ }^{89}$ The effect of Farias' book on a reading public aware of Heidegger's fame, ambivalent toward poststructuralism, and keen on absolving itself of a problematic past, was unsurprisingly violent. Writings in papers and magazines quickly turned into tracts willing to indict Heidegger and close his case, as the scandal in its early stages operated more as a oneway street than a discussion. ${ }^{90}$

The first direct response came from Jacques Derrida, ${ }^{91}$ in an interview which he later called premature. ${ }^{92}$ Derrida noted that Farias was incompetent in reading Heidegger and offered little new material; Jambet's preface was a "hodgepodge," a "Franco-French, not to say provincial, operation... comic and sinister" (HPH 187). ${ }^{93}$ While agreeing that Heidegger's Nazism was not coincidental, Derrida turned the tables to ask:

why deny that so many "revolutionary," audacious, and troubling works of the $20^{\text {th }}$ century have ventured into or even committed themselves to regions that, according to a philosophy which is confident of its liberal and leftistdemocratic humanism, are haunted by the diabolical? (HPH 182)

Already under fire for the collaborationist, Anti-Semitic writings of his late friend Paul de Man, Derrida pointed somewhat hastily to his own distance from Heidegger, saying that he had shown his reservations in each of his references to Heidegger, "as far back as they go" (HPH 183). Derrida insisted that deconstruction was neither reducible to Heideggerianism nor amounted to a methodology resting on Heideggerian foundations. In support of this response, he pointed to his own De l'esprit that was about to be published, following his lecture at the Heidegger: questions ouvertes conference from March 1987. Farias responded to Derrida's interview by pointing to his own research, implying that Derrida just couldn't face the facts. ${ }^{94}$ The latter responded in turn, noting that "anyone interested in Heidegger" had known, for 


\section{STEFANOS GEROULANOS}

decades even, certain facts that Farias was pointing out as new. For Derrida, none of the new facts changed Heidegger's political disaster, which Derrida saw himself as having analyzed throughout his intellectual life, and against which he continued to call for a deconstructive analysis of "all Nazisms" in Heidegger's texts (hence implicitly granting a central anti-Heideggerian demand). ${ }^{95}$ Read in context, Derrida's quick response did not serve him well. Press debates often present their public with binary oppositions, and this one at first pitted Farias against Derrida. As he was the first to confront Farias' book and claimed that there was nothing new to it, Derrida unwillingly picked up the mantle of the apologist — an apologist that he had certainly never been. He then aligned himself with (what we might call) French phenomenology, referring to Levinas, Blanchot, and Lacoue-Labarthe-whom he saw as influenced by Heidegger and as having confronted his politics (HPH 182). But the interview did not suffice to suggest that he was taking a position against both partisans and detractors: sporting a photograph of him in fashionably defiant pose, Le Nouvel Observateur presented Derrida as a public dancer for Heideggerian apologetics. Even his expression of reservations backfired, suggesting dishonesty on his part: how could he deny the importance of Farias while only now publicly presenting political reservation? A subsequent exchange with Farias only exacerbated this feeling, indirectly granting Ferry and Renaut precisely the ground they required to repeat their attack. ${ }^{96}$

Much more explicitly apologetic positions were offered in January 1988, in a compendium in Pierre Nora's journal Le Débat. François Fédier, Henri Crétella, Michel Deguy and Pierre Aubenque all repeated versions of the Beaufret argument, arguing that Farias' book was not a reliable guide to Heidegger but only an example of "the mediocrities' assault" on him. ${ }^{97}$ The issue had been analyzed in the past, their argument went, and it was high time that this be put aside to let "serious work" based on Heidegger continue. ${ }^{98}$ Most importantly among them, Fédier argued that Farias' book was useless because of its "harmful intention" to identify Heidegger with Nazism. ${ }^{99}$ Fédier tried to disqualify this intention, partly by pointing out that two German publishers had rejected Heidegger et le nazisme before it was published in France, partly by denouncing "errors" in the interpretation. ${ }^{100}$ Fédier soon also published a book-length analysis of Farias in a book of his own, Heidegger: anatomie d'un scandale. Fédier's book (no less of a diatribe than Farias') aimed again at errors in Farias' text, often deciding what amounts to a mistake via a juxtaposition of 


\section{SLAUGHTERBENCH OF HUMANISMS}

Farias and Heidegger's remarks and an obvious partiality toward the latter. ${ }^{101}$ Through a hyperbolic reprise of the Beaufret line of defensethough almost without mention of Beaufret-Fédier claimed to show that these mistakes disfigured the story and were nothing but "calumnies" intended to stop others from thinking about the master. ${ }^{102}$

Like other Heideggerians, Fédier had a very serious point, and to a great degree helped show the weakness of Farias' claims-yet due to both his own partisanship and his methodological limitations, they did not manage to overcome or even seriously counter the Farias effect. Indeed the attempt to buttress a defense by using the Beaufret line was badly received. Two sympathetic letters of Beaufret to the revisionist historian Robert Faurisson from 1979 had recently been published in Faurisson's journal, implying that Beaufret had also been a revisionist. ${ }^{103}$ There is little indication in the letters that Beaufret echoed the very ferocity of Faurisson's own 1980s revisionism, but the event was not without precedents. In 1986 Emmanuel Martineau lamented in an interview that with the passing of time, Beaufret's politics had moved with increasing speed toward the extreme right. ${ }^{104}$ And, more recently, Dominique Janicaud has reported a small "Beaufret affair" at the Ecole Normale Supé rieure in 1968, ${ }^{105}$ where Roger Laporte apparently told Derrida of anti-Semitic comments by Beaufret, to whom Laporte had been close. Derrida was concerned, insofar as his "Ousia and Grammé" was being published in a Festschrift for Beaufret. ${ }^{106}$ Having already expressed doubts — he was neither among Beaufret's students nor felt himself close to them-Derrida approached a no less shocked Maurice Blanchot, but Beaufret fiercely denied all this in an argument with Laporte in Derrida's office. Derrida and Blanchot left their essays in the volume, asking Plon to publicize their discomfort (HF 2:99). By 1987, his role in the resistance now forgotten, Beaufret's problematic post-war politics rendered reference to him (even among some in his closer circles) suspicious. It was probably for this reason that Fédier sought not to compound difficulties and almost never cited Beaufret's texts in support of Heidegger. ${ }^{107}$

\section{Humanisms, Antihumanisms, Modernities}

If the immediate affair produced a rather harsh dichotomy, its effect in a broader context was much more interesting. "In France, a sky has fallen... le ciel des philosophes," remarked biographer Hugo Ott, viewing the difficulties facing those who stuck to Heidegger's side. 


\section{STEFANOS GEROULANOS}

Orthodoxy was no longer convincing, and the position inspired by Heidegger's work that survived the debate was not at all Heideggerian in spirit. The two most notable avant la lettre responses to Farias were two books by Lacoue-Labarthe ${ }^{108}$ and Derrida, ${ }^{109}$ both of which had been in the making for a number of years and were published shortly after Farias' own. Neither of these works was supportive of Heidegger; instead, each treated significant aspects of his thought as dishonest and politico-philosophically worrying. The two texts were not Heideggerian responses to Farias in the first place, ${ }^{110}$ but aimed at a "third" position, that of a Heidegger-inspired antihumanism that made considerable use of the thought of Levinas and Maurice Blanchot, and differed considerably from both Heideggerians and antiHeideggerians. ${ }^{111}$ It might be unfair to indiscriminately place the two books, - in addition to the positions of others, like Levinas - under the same mantle. Their modes of argumentation are different, their conclusions even more so. Yet both reject fundamental Heideggerian principles, while specifically retaining Heidegger's critique of Enlightenment humanism, two aspects that distinguish them from orthodox Heideggerian arguments, which continued to accept Heidegger's oeuvre in toto without paying particular attention to the antihumanist question.

In fact, both Derrida and Lacoue-Labarthe insist on this question. Their arguments see Europe as a dark continent of political/ politicized philosophy, in which systems of thought and engagement are fundamentally influenced by unsavory political linkages, and where humanism can offer no more than the illusion that one stands on better ground than one's adversaries. ${ }^{112}$ Hence, the "contaminated" metaphysical and cultural realms of Europe could not claim conclusive opposition to its horrors. "Though not all positions and forms of complicity are equivalent," for Derrida "they are irreducible" (OS 40).

And even if, far from any desert, [Nazism] had grown like a mushroom in the silence of a European forest, it would have done so in the shadow of big trees, in the shelter of their silence or their indifference, but in the same soil ... In their bushy taxonomy, they would bear the names of religions, philosophies, political regimes, economic structures, religious or academic institutions. In short, what is just as confusedly called culture, or the world of spirit. ${ }^{113}$

Derrida then reads Nazism as a metaphysical choice among others. Ultimately, it was one's "ascription" to any metaphysical choice that 


\section{SLAUGHTERBENCH OF HUMANISMS}

enabled and even appointed a politics as disastrous as Nazism. Spirit provides here the crucial terminological problem — as it evokes, at once, Hegel and certain conservative and nationalist political claims of considerable significance for 1930s Germany. For Derrida, the early Heidegger had considered Geist (spirit) a metaphysical proposition to be overcome-Sein und Zeit only retained it in quotation marks (OS 1; ch. 3,4). At this point, Derrida already argued against the use of the term in quotation marks, noting that through them, Heidegger, despite his reservations, offered at least hospitality to its meaning (OS 24, 279). But in Heidegger's Rectoral Address of 1933 and his Introduction to Metaphysics of 1935, and marking his crucial turn toward Nazism, Heidegger put the quotation marks aside, and made the restoration of German "Spirit" the centerpiece of his engagement with and expectation from Nazism (OS ch.5-6). This introduces Derrida's underlying "argument," namely that Heidegger identified with National Socialism on the basis of his embrace of a spiritual revolution against the decadence of the European spirit. Heidegger attempted the spiritual rejuvenation of Germany through Nazism without recognizing that, by retreating from his earlier destructive analytic, he plunged into the very metaphysics he wanted to overcome. In seeking the "spiritual" rejuvenation of Germany, its university, and Europe as a whole, Heidegger's program became "entangled with the worst." A care for the German Spirit thus links a personal to a philosophical politics. Thus, Heidegger became an accomplice to the metaphysical nihilism that he nominally opposed, a nihilism Derrida also discerned in other motifs of his thought, such as his treatments of animality and evil (OS $47-57,80)$. In speaking the language of spirit, Heidegger convinced himself of standing apart from the worst in Nazism-racialism, biologism etc - all the while sheltering its basic foundations. Only in 1953, in his analysis of Trakl, did Heidegger try to return to the analytic that he had abandoned in $1933 .{ }^{114}$

This was not a new vein of Derrida's reading of Heideggerhis ambivalence is visible already from the mid-60s. But from the mid80s on, Derrida's work concentrated increasingly on political prolems (e.g. nationalism), while also moving toward an increasingly vocal critique of Heidegger ${ }^{115}$ without disavowing its dependence on him. ${ }^{116}$ In $O f$ Spirit, Derrida was both philosophically critical of and contemptuous toward Heidegger, calling his personal and intellectual behavior "mediocre and hideous" (OS 121n.1). But at the same time, Derrida denounced the intent to "burn" Heidegger — hence the book's repeated 


\section{STEFANOS GEROULANOS}

references to fire and ash, as well as to Helvetius, who saw his own $O f$ Spirit denounced and burned. ${ }^{117}$ Derrida played with a motif of "too late," pointing out that it was perhaps too late to make a difference regarding Heidegger's Nazism. More provocatively for the mid-1980s, he compared Heidegger's discourse on the destitution of the spirit to works of Edmund Husserl and Paul Valery, thinkers traditionally read as opponents and victims of fascism. Though they did not support fascism, such "victims," Derrida noted, were no less exclusionary when struggling against a "destitution of European spirit." Instead, they took a position analogous to Heidegger's, a position that contemporary humanism avoided challenging (OS 60-2). ${ }^{118}$

Lacoue-Labarthe's approach often echoes Derrida's but takes pains to locate itself closer to Levinas and Blanchot. Throughout the 1980s, Lacoue-Labarthe's engagement with Heidegger included an analysis of Heidegger's effect on Celan as well as a close reading of Heidegger's Rectoral Address. ${ }^{119}$ Still more critical toward Heidegger than Derrida, Lacoue-Labarthe argued that the Nazi engagement was anticipated in Heidegger's earlier writing and continued throughout his life, albeit not in terms of direct political engagement. ${ }^{120}$ Like Derrida, Lacoue Labarthe treated the Rectoral Address as central to Heidegger's philosophical oeuvre, and extended this critical approach to suggest that "only Heidegger allows us to understand National Socialism" (FP 72). He also expressly criticized orthodox Heideggerians "for completely missing the point," especially as regards utterances that they "endlessly" repeated, such as Heidegger's 1955 claim, at Cérisy, ${ }^{121}$ that "there is no Heideggerian philosophy." ${ }^{122}$ Lacoue-Labarthe took seriously Heidegger's claim that his work represents an attempt to reach "pure thought," but, in a turn that would have pleased Adorno, used it to show that this attempt at purity is inextricably linked to Heidegger's Nazism. ${ }^{123}$ Beyond the fundamental problems of Being and Time, especially the "question of Being" (which Lacoue-Labarthe accepts as fairly unproblematic [FP 25]), Heidegger's work appeared to him a philosophy deeply immersed in political arguments, especially in when it was involved in seemingly harmless analyses of poetry and techné. Relying on Levinas' assault on ontology as forever bearing with it power and violence (for instance, in De l'existence à l'existant), as well as on Derrida's critiques of Heidegger's supposed antihumanism, LacoueLabarthe argued that, like many others, Heidegger found nothing in the Old World with which to resist "the irruption of the so-called "New World," and no reason to evade the challenge which presented 


\section{SLAUGHTERBENCH OF HUMANISMS}

itself in Nazism" (FP 43). For Lacoue-Labarthe, this was the gist of Heidegger's Nazism, an arche-fascism readable as national aestheticism especially in his supposed resurrection of "a Greece which never really saw the light of day." ${ }^{24}$ Heidegger not only heralded a "caesura" with the recent past but retained it long after his recognition of Nazism's disinterestedness in a rejuvenation of Being. ${ }^{125}$ Hence, the "inner truth and greatness" of national aestheticism stayed with Heidegger well beyond the 1930s: Lacoue-Labarthe's concerns with the originary, "the model," "the will itself" and poetry, thus turned against Heidegger's MetaGreece, ${ }^{126}$ claiming it was Heidegger's national aestheticism that facilitated his greatest political failure, namely to think the Holocaust. ${ }^{127}$ Insofar as the debate was concerned, Lacoue-Labarthe also argued that Heidegger neither was the only Nazi nor belonged to the worst, and rejected the anti-Heideggerian attempts to "burn" Heidegger as ludicrous (FP 178-80). ${ }^{128}$

A similar argument also formed part of Jean-François Lyotard's Heidegger and "The Jews," published later in the year, which attempted to set rules for the political debate and considered the insufficiency of Heidegger's postwar role in the examination of issues raised by the Holocaust. While sharing many of Lacoue-Labarthe and Derrida's presuppositions, Lyotard argued against Lacoue-Labarthe's understanding of the Holocaust as a "caesura" in Western history and his treatment of " "national aestheticism." " 129 For Lyotard, these concepts allowed Lacoue-Labarthe to poeticize aspects of the Holocaust but in the end failed to explain it. ${ }^{130}$ Concluding mostly in favor of Heidegger, Lyotard supported the critical dimension in Derrida and LacoueLabarthe, positing another critical explanation of Heidegger's silence on the Holocaust. ${ }^{131}$

During the 1987 debate, Derrida's and especially LacoueLabarthe's Heidegger-inspired antihumanism was generally represented in Le Nowvel Observateur, which, in addition to Derrida's November interview, included a dossier on Heidegger in January. ${ }^{132}$ The introduction to the articles had few kind words for Fédier, characterizing him as a credo-follower, "extra-dry and non-defrocked." 133 Instead, figures such as Levinas, Blanchot and Gadamer argued in these pages that the "Heidegger affair" had not really changed their opinion of Heidegger, which had always been critical of his failings, especially of the failure "to think the Apocalypse of Auschwitz." The gesture of rejecting Fédier is a symptom of major importance in their effort to show that not everything that had come from Heidegger could be characterized as 


\section{STEFANOS GEROULANOS}

Heideggerian. Conversing with each other, ${ }^{134}$ their texts rejected the present trial of Heidegger, "conducted by the card-carrying antiHeideggerians," as impertinent and intellectually dishonest. ${ }^{135}$ Instead, the "refusal" or "failure" to think Auschwitz became a central claim among these thinkers as well as Derrida and Lacoue-Labarthe-and this dossier was its clearest exposition. In what might be dubbed the College International de Philosophie/Nowvel Observateur approach of the debate, the dossier (and the books by Derrida and Lacoue-Labarthe) offered a clear political and philosophico-political understanding of the distance of French phenomenological and post-phenomenological thought from both Heideggerians and detractors. ${ }^{136}$ This argument, veering between a delicate Heidegger-inspired antihumanism and a qualitative surpassing of Enlightenment humanism, claimed its superiority through a more disillusioned reading of the century, a more careful contextualization of philosophy, and a more consistent engagement with ethics. Specifically, this position took up in the debate a thinking of the Shoah as the Apocalypse, which it combined with mourning for the failure of "the pinnacle of Western thought," Heidegger, to think and think against this catastrophe, which they regarded as "the revelation of the essence of the West." 137

On the other end of the spectrum regarding an intellectual conception of modernity and Heidegger's philosophical importance stood a new book by Ferry and Renaut, published in early 1988 as Heidegger and Modernity. In part a polemical intellectual history against French phenomenological thought and in part an discussion of connections between modernity and humanism, the volume continued the authors' effort to restore meaning to humanism in an explicitly Sartrean manner (HM 3). Insofar as the debate was concerned, Ferry and Renaut saw their earlier campaign contra Heidegger proven right by Farias (HM 9, 67-72) and took up a particularly hostile tone against Derrida and Lacoue-Labarthe. ${ }^{138}$ In an anecdotal public-philosophical idiom, they took issue with the work of both, especially with a seemingly minor supposition of Lacoue-Labarthe, that "Nazism is a humanism insofar as it rests on a definition of humanitas which it sees as more powerful and effective than any other" (FP 138). Echoing Heidegger and Derrida, Lacoue-Labarthe had rejected the universality of humanism and the ahistorical claims of its present adherents regarding its eternal value and righteousness as well as its simple, binary opposition to "antihumanism." Ferry and Renaut objected that this was an essentialist definition of humanism, in other words, that Derrida and 


\section{SLAUGHTERBENCH OF HUMANISMS}

his students' "misunderstood" (a) Nazism as exemplary of a certain modernity, and (b) humanism as a reflection on the essence of the subject. ${ }^{139}$ Heidegger did not become a Nazi because through an excess of metaphysical humanism, they suggested, but because of a dearth thereof (FHW 294-5). Ferry and Renaut's universalist liberal humanism (HM 192-3) hinged at this point on a rather crude identification of Derrida and Lacoue-Labarthe with a radical conservative anti-modernist illiberalism (HM 71-3, 155-8). ${ }^{140}$ What they could not accept was Heidegger's rejection of humanism as part and parcel of a modernity inclusive of Nazism, Stalinism and American individualism (all of them widely seen in the French intellectual scene as the exemplary evils of the late 1940s). For them, it was the rejection of the human as tainted that was to be rejected if one were to become Heidegger's shepherd of Being. ${ }^{141}$

A similar position was invoked in the republication in book form of Bourdieu's 1975 article L'ontologie politique de Martin Heidegger in early 1988. In an interview with Libération, Bourdieu took Derrida to task over De l'esprit, suggesting that Derrida was building on his (Bourdieu's) earlier work and had been put in a particularly difficult position by Farias' book. ${ }^{142}$ By this point it was March 1988 and Derrida, tired of defending himself over his alignments with de Man and Heidegger, fired back an angry letter, arguing that Bourdieu's "toldyou-so" interview included factual inaccuracies (that Derrida had accepted without concern Bourdieu's analysis) and was, as an analysis of Heidegger, "radically insufficient". ${ }^{43}$ He noted, objecting to Bourdieu, that he was under no particular pressure because the vigilance of his readings of Heidegger confirmed his non-solidarity with Heidegger's engagement. While Bourdieu was arguably more influenced by Heidegger than he allowed, what was significant in his participation in the debate was the impression he and Liberation insistently gave, namely that an honestly leftist position had to now confront its debt to Heidegger and reject him. Given that a certain "second-hand" Heidegger had been important to the Hegelian and Althusserian strands of French Marxism in the 60s and 70s, and also his rejection from a strictly leftleaning political world confirmed the new distance between Heideggerianism and the remnants of that left—even its "popular" non-specialist strands. Interestingly enough, the position of Renaut, Ferry, Bourdieu and Libération, was occasionally not that far from the position staked by Derrida, Lyotard and Lacoue-Labarthe (the C.I.P. view). Both sides rejected Heideggerians for sanitizing the Nazi past; 


\section{STEFANOS GEROULANOS}

both rejected Heideggerian utopias, whether these concerned Dasein itself, MetaGreece or the task of poetry. But the two positions differed on the importance of humanism in liberal democracy. Remaining within the critique first established by the Letter on Humanism and later transformed by (among others) Derrida's "Ends of Man," Derrida, Lacoue-Labarthe, Blanchot and Levinas rejected critics' classical metaphysical humanism as insufficient. Ferry and Renaut, on the other end, understood phenomenological antihumanism as a clause of a world surpassed, and implicitly rejected the older connection between antihumanism and the intellectual left, forged during the 1950s by the Letter on Humanism, Beaufret, the Arguments group, and the Kojèvian legacy as an antimodernism dedicated to obstructing liberal hopes.

\section{Aftermath}

The debate continued until the middle of 1988: journals continued to publish dossiers regarding "the truth about Heidegger" well into June, while mini-debates in the press continued until at least March. ${ }^{144}$ Heidegger's name and legacy was indeed marred-but to what extent? Certain effects became quickly noticeable. First, the prodigious amount of writing on Heidegger was somewhat reduced. Between 1989 and 2000, France saw the publication of about 100 books on the subject of Heidegger, fewer than the mid-eighties trend of publications would suggest but nevertheless a most substantial corpus. Few philosophers continue to interpret the world from the strict perspective of such Heideggerian fundamentals as a MetaGreece of poetic thinking. For a while, claims to be working in ontology routinely demanded political clarifications and a taking of sides: in his first footnote to Being and Event, published in 1988, Alain Badiou included a discussion of his distance from both orthodox Heideggerians and their humanist critics. ${ }^{145}$ Nevertheless, though the strict, uncritical French following of Heidegger came largely to an end, it is premature to conclude, with Ferry and Renaut (and to a certain degree with Rockmore's pessimism), that Heidegger is finished in France. In the very least, phenomenologians and philosophers deeply indebted to Heidegger continued to hold very significant positions. ${ }^{146}$ In 2003 , in another major institutional "success," Heidegger became an established part of the questions for the agrégation en philosophie. Moreover, as noted already, the post-' 87 corpus of works is significant and, for the most part, adequately informed by the problem of Heidegger's Nazism. A 


\section{SLAUGHTERBENCH OF HUMANISMS}

generation of younger, somewhat more critical if still deeply indebted philosophers has taken up the space left open by the Heideggerians' collapse, approaching him through a more careful perspective and often centering on his very early work. It is also too soon to assess if a relative decline of Heidegger's influence, in favor of the more recent turns toward philosophies of life (notably toward Bergson and Deleuze) and, especially, the turn toward analytic and post-analytic philosophyis either of long-term significance or related to the political question.

In the 1990s, the major orthodox Beaufretians remained Fédier and Vezin (both of them outside the university). Fellow travelers like Frédéric de Towarnicki, Walter Biemel and Roger Munier took up a more contemplative, lamenting tone in their later work, publishing mémoirs rather than analyses. ${ }^{147}$ Fédier's own essay collection Regarder Voir, his album of photographs, ${ }^{148}$ and his Gallimard translation of Heidegger's political texts ${ }^{149}$ further adopted a melancholic apologetics which suggests a lack of comfort in the intellectual domain, and a continuing feeling that a media event such as the 1987 affair stopped work that had more to offer. In a sense, Fédier's own (and often disagreeable) argument that Heidegger's choice of Nazism as the only "honest" option available to him in 1933 in the late 1990s has not substantially helped his defense. ${ }^{150}$ Anti-Heideggerianism has also continued, though without the intensity built up in the $80 \mathrm{~s}$. While neohumanism became politically popular and a significant intellectual force, it is not unfair to claim that the popular success of its philosophical impulse was not accompanied by a major academic rise and has resulted in much hostility among philosophers who saw neo-humanism as a rejection of twentieth-century trends in toto. The most important antiHeideggerian arguments to be published during the 1990s were Henri Meschonnic's Le Langage Heidegger, Jean-Pierre Faye's Le Piège, both of which see the Farias events in positive light (Meschonnic especially). ${ }^{151}$ Le Piege is the latest of Faye's attempts to explain the problem that Heidegger poses for contemporary thinkers, and consists mostly of a repetition of earlier work resonating well with the Liberation-led disavowal of Heidegger and situating him squarely in the middle of Le Langage Meurtier, a new version of his classic Langages Totalitaires. Meschonnic's more extensive treatment attempts to eject Heidegger from linguistics and poetry: weaving his argument around the 1987 affair, Meschonnic argues that Heidegger understood little of poetry and that his language, right down to the poetry it claims to authentically reinterpret, remains deeply flawed. ${ }^{152}$ The publication of Heidegger's texts and courses from 


\section{STEFANOS GEROULANOS}

the 1930s also provoked occasional debates. ${ }^{153}$ Towering over these was the 2005 publication of Emmanuel Faye's Heidegger: l'introduction du nazisme dans la philosophie, which brought an especially harsh interpretation of Heidegger's politics and philosophy and has maintained a certain pressure: the very subtitle of the book ("The Introduction of Nazism into Philosophy") speaks clearly to the rejection of Heidegger sought by Faye ${ }^{154}$ Faye's argument, which includes readings of Heidegger's especially disconcerting courses from his time as Rector and the aftermath of this tenure has been particularly significant and visible as a criticism of French thought, particularly as Faye argues that Heidegger subjected philosophy to National Socialism's goals and tropes, and that a rejection of his thought is necessary for the rehabilitation and denazification of philosophy. Following the publication of Faye's book, a new and broad debate erupted, notably on the internet and even on television, ${ }^{155}$ with a first response by Fédier and others coming by way of an email manifesto. ${ }^{156}$ In early 2007, a number of thinkers around Fédier extended this response to a book-length response to Faye, Heidegger à plus forte raison, once again aiming to prevent the political criticisms of Heidegger from turning into a wholesale philosophical rejection of Heidegger's thought. ${ }^{157}$

What is missing in the present debate, even though the evidence is far more politically damning than was Farias' stilted synthesis, and even though is the neohumanist fervor of the 1980s, which transformed the problem of how to interpret and deal with Heidegger's politics into a cause célèbre against the "philosophy of the 1960s." Faye does argue against the French Heideggerian influence, but without a clear philosophical alternative. Recent debates in the press (particularly around questions of eugenics and anti-Semitism), have more or less allowed an acceptance of Heidegger as a Nazi and as an at least mild antiSemite without denying the significance and influence of his thought. ${ }^{158}$ Moreover, for the first time in 2006, Heidegger became one of the two major philosophers to be examined in the French philosophical agrégation - one of the pillars of academic respectability in France. ${ }^{159}$ The political question has also been a significant philosophical topic, for example at the five-day conference at Strasbourg (Heidegger: le danger et la promesse) in November-December 2004, which involved figures such as Badiou, Lacoue-Labarthe, Nancy, and Peter Sloterdijk.

Certain Heideggerians also presented more vocally their distance from the cocoon. Jean-Michel Palmier, who had in 1945 brought Beaufret's first letter to Heidegger and had cautiously defended 


\section{SLAUGHTERBENCH OF HUMANISMS}

Heidegger on the political issue by citing his distance from militants like Ernst Krieck, published a long article treating most recent accounts of Heidegger's politics as "plausible."160 While retaining sympathy for the classical Heideggerian thesis, Palmier argued that divergence of opinion in the dispute undermined Heideggerian claims to a privileged access of the master's text. ${ }^{161}$ Thinkers like Janicaud, Haar, Dastur, Catherine Malabou, and Jean-François Courtine have continued (often harsh) critiques of Heidegger from within a broader phenomenological and post-phenomenological viewpoint. Courtine wrote in 1990 that Heidegger essentially distorts dialogue into monologue, occluding difference, opposition and genuine exchange. ${ }^{162}$ And Dominique Janicaud, who in 1963 had supported Heidegger without reservation ${ }^{163}$ conceded in L'Ombre de cette pensée $e^{164}$ the significance of the political problem. Janicaud located the extremist threat solidly within Heidegger's thought - though for him it was "the thought of man's finitude in history and the radical historicity of Dasein" that facilitated the disastrous engagement (HF 1:388). In his last published work, Janicaud provided the meticulous Heideggeren France, whose most interesting and questionable positions concern his downgrading of the major political thematics regarding antihumanism and the Heideggerian left. It includes a serious, frequently spirited defense of deconstruction's debt to Heidegger, a defense that often underplays the anti-anthropological and anti-subjectivist positions in Derrida and Lacoue-Labarthe. Meanwhile, Derrida's “Levinasian" political or ethical turn has further framed his critical analysis of Heidegger. The most obvious notable texts in this vein are his interview with Jean-Luc Nancy Apres le sujet qui vient? ${ }^{165}$ and Apories, where Derrida argued against Heidegger's prescription of the "authentic" projection of oneself unto death. Echoing Levinas', Löwith's, and Janicaud's worry over the political implications of Heidegger-inflected finitude, Derrida argued the impossibility of thinking one's own proper death: in accord with Heidegger that death is the innermost possibility of Dasein, that of its impossibility, Derrida countered, echoing the argument of Bataille, Blanchot and Levinas on the impossibility of experiencing death, that death is life's "most ex-propriating [and] inauthenticating" dimension. ${ }^{166}$ In this context, effects of the 1987 debate are discernable in deconstruction's heightened attention to questions of ethics and religion, which can be partly understood as a reaction to the neohumanist and multiculturalist tendencies in French thought that Derrida repeatedly criticized. The deaths of Derrida in 2004 and Lacoue-Labarthe in 2007 


\section{STEFANOS GEROULANOS}

(as well as of Dominique Janicaud in 2001 and Maurice Blanchot in 2003) have left many of these questions open or up for a different kind of development.

What were the stakes of the 1987 Heidegger affair? Maybe it is important to start with what these stakes were not. The collapse of official Heideggerianism was itself not of primary importance. It indicated that Heidegger's name and oeuvre no longer form the basic foundation of a specific movement in French thought: most orthodox Heideggerians had seen their influence decline in the intellectual milieu since the 1960s, and the Farias affair further marginalized the Beaufretians. Second, the debate surprisingly took on no questions concerning the gauche heideggérienne during the third quarter of the century - though the Heideggerian Left was helped in its own decline as well. With the emphasis on Nazism, the Heideggerian Left, which had been extraordinarily important in the late 1960s, became not merely a paradox but a contradiction. This affected the thought and present political choices even of figures like Derrida, and indicates a concern by neohumanist critics to present Heidegger's French offspring as downright reactionaries, not as a part of a problematic left. Similarly not explicitly at stake in 1987 was the debt of postmodernism in general to Heidegger. Lyotard's position in 1987-1988 had little to do with "postmodernism," while Baudrillard's short media "necrology" of Heidegger was quickly forgotten. ${ }^{167}$ Finally, Bourdieu's contribution against Heidegger measured against his debt to structuralism suggests that the remnants of structuralism were no longer a milieu in need of overcoming.

Now for the importance of the affair: if French Heideggerians had succeeded in the past in heroizing their master, this was largely because they had appealed to a 1930s, 1950s and 1960s intellectual public that conceived of modernity as a battlefield of ontological utopias and was concerned with evading the embarrassing and over-optimistic politics of humanist partiality. The Heidegger affair showed how a community of readers that developed during the 1960s and supported a widespread and not necessarily academic thinking during the period was now evaporating - hence the difficult position that Derrida and others were indeed brought to, including even Paul Ricoeur, hardly a Heideggerian himself, who called the affair anti-French and antiphilosophical. ${ }^{168}$ This has also affected and facilitated "resistance to theory" and the appropriation of French thought in U.S. academiaoften unfairly presented as a thinking "no longer alive" in France. 


\section{SLAUGHTERBENCH OF HUMANISMS}

Parallel to deconstruction's turn toward ethics and religion, the rise of Christian and religiously-inflected readings of Heidegger in France since the early 1980s (in the hands of Jean-Luc Marion, for example, not to mention Jean-Luc Nancy's work, which has a more complex and ambiguous relationship to both Heidegger and Christianity than does Marion's) can also be attributed to a certain decline of the atheist and antihumanist inspiration that Heidegger had offered since the 1960s. Nancy has largely managed to steer his own dependency on and critique of Heidegger clear of the debates. ${ }^{169}$ The problem with this (in itself philosophically valuable) development is that it excises from contemporary thought one of the most significant and elaborate arguments for the epistemological and ontological significance of antifoundationalism and philosophical atheism, hence contributing to a re-ideologization of philosophy that is no less troubling than the status quo ante 1987.

At stake in 1987 was the dissipation of that community by the 1980s development of a rhetoric of human rights and liberal democracy, a rhetoric that in 1987 played out as the most significant counterpart to strands of thought (and the poststructuralist tradition) who instead, without rejecting human dignity, did not use "human rights" to reject dimensions of a past that had not taken them as a fundamental premise. Derrida was not the only thinker voicing concerns that this rhetoric, especially in Ferry \& Renaut's terms, summarily excised from philosophy significant questions and foreclosed a serious treatment of political and philosophical legacies. Jambet, Ferry, Renaut and others argued (rather too fast) for a dismantling of past antimodernisms (anti-modern standing in for anti-liberal) whose continuing role operates against the future of French philosophy, by blinding thinkers to the political implications of a philosophical world that had to be overcome. ${ }^{170}$ Their opposition to a "thought of 68 " was not just an attempt to render philosophy politically agreeable by excising troubling origins but a concern over the continuing import of a thought that rejected the fundamental premises and promises of the Franco-European present. Still, it is impossible to ignore the pamphleteering manner through which Ferry and Renaut made their point, accepting liberalism's name and position without seriously locating it either in its troubled history or even beyond it.

Ascending neo-humanism thus clashed with deconstruction by treating the latter's conception of the subject as one that engaged in a "facile" cosmopolitanism, but evaded the questions and potentials 


\section{STEFANOS GEROULANOS}

of a liberal-democratic thinking. If deconstruction's subsequent insistence on ethics and religion can be partly understood as a reaction to the 1980s political charges against it, 1987-88 should be read as a watershed that has led to more recent debates involving religion, ethics and multiculturalism. As Franco-French (dit Derrida) as it was antiFrench (ditRicoeur), the Heidegger affair forced a realignment of faultlines and public divisions in French thought by emphasizing questions on the rigor of definitions of humanism and the debts that trouble philosophical innovation. 1987 was a debate that continues to influence French thought today, if not with direct concern over humanism, at least under the continuing concerns with race and multiculturalism, the connections to a dark twentieth century and the possible futures of liberal democracy.

New York University

\section{Notes}

For their generous support and criticism, I am most grateful to Françoise Coblence, Paola Marrati, Anson Rabinbach, and the late Christian Delacampagne and Fernando Gil. I would also like to thank Princeton's Davis Center for Historical Studies for the fellowship that assisted my research into this project in the summer of 2000 .

1 The book was translated into the French from German and Spanish; in Germany it was first published in late 1988 with a preface by Jürgen Habermas: Viktor Farias, Heidegger und der Nationalsozialismus (Frankfurt am Main: S. Fischer, 1989).

${ }^{2}$ The main texts of the two sets of earlier debates on Heidegger and politics, namely the 1946-47 debate in and around Les Temps modernes, and the greater 1960s debate were as follows: Armand Cuvillier, Les Infiltrations germaniques dans la pensée française (Paris: Universelles, 1945); Maurice de Gandillac and Fréderic de Towarnicki, "Deux documents sur Heidegger," Les Temps modernes, 4 (Jan 1946); Karl Löwith, "Les Implications politiques de la philosophie de l'existence chez Heidegger," Les Temps modernes 14 (Nov 1946); Eric Weil, "Le Cas Heidegger" and Alphonse de Waelhens, "La Philosophie de Heidegger et le nazisme," Les Temps modernes 22 (Jul 1947); Karl Löwith, "Reponse à M. de Waelhens," Les Temps modernes 35 (Aug1948); Jean-Pierre Faye, "Heidegger et la révolution," Médiations 3 (Autumn 1961), 151-159 (followed by a dossier of Heidegger's political texts); Jean-Pierre Faye, "Heidegger sur Heidegger," Médiations 5 (Summer 1962), 135-154; Aimé Patri, "Un Exemple d'engagement," Le Contrat social (1962:1), 37-42. Etiemble, "Vive Le Zen!," France-Observateur (Nov. 28, 1963), 15-16; Dominique Janicaud, "Heidegger Nazi?" France-Observateur (Dec. 12, 1963), 2; Alfred Grosser, "Réponse à M.Janicaud," France-Observateur (Dec. 19, 1963), 3; J. Vial, "Article sur l'Univérsité," France-Observateur(Dec. 19, 1963), 3; Jean Beaufret, "Heidegger 


\section{SLAUGHTERBENCH OF HUMANISMS}

et le Nazisme," France-Observateur (Dec. 31, 1963), 2; Armand Ettedgut, "Heidegger et le Nazisme," France-Observateur (Jan.9, 1964), 12; Beaufret, "Heidegger et le Nazisme," France-Observateur (Jan. 16, 1964), 3; Od. Laffoucrière and J. Nancy, "Heidegger et le Nazisme," France-Observateur (Jan. 23, 1964), 2; Jean Beaufret, "Heidegger et le Nazisme," France-Observateur (Feb. 6, 1964), 2; Jean-Pierre Faye, "Quelques rémarques àpropos de l'affaire Heidegger" France-Observateur (Feb. 13, 1964), 2; François Fédier, "Trois attaques contre Heidegger," Critique 234 (Nov 1966), 883-904; Robert Minder, "Langage et nazisme," Critique 237 (Feb 1967), 284-287; Jean-Pierre Faye, "La Lecture et l'énoncé," Critique 237, 288-295; Aimé Patri, "Serait-ce une querelle d'Allemand?" Critique 237, 296-97; François Fédier, "Une Lecture Dénoncée," Critique 242 (Jul 1967), 672-686; "Lettre de Heidegger à François Bondy," Critique 251 (Apr 1967), 433-35; François Fédier, "Le Point," Critique 251, 435-37; Jean-Michel Palmier, Les Ecrits politiques de Heidegger (Paris: L'Herne, 1968); Pierre Bourdieu, "L’Ontologie politique de Martin Heidegger," Actes de la recherche en sciences sociales (1975:5-6). The above list, more elaborate than others presently in existence in English, is not exhaustive, but it at least demonstrates that the question was not unknown or covered up, even during the 1940 s and $1960 \mathrm{~s}$.

${ }^{3}$ The main accounts of the Farias effect are as follows: Luc Ferry and Alain Renaut, Heidegger et les modernes (Paris: Grasset [Figures], 1988), translated as Heidegger and Modernity (Chicago: University of Chicago Press, 1990); Tom Rockmore, Heidegger and French Philosophy: Humanism, Antibumanism, and Being (London: Routledge, 1995); Tom Rockmore, "Heidegger's Nazism and the French Debate" in Christopher Macann, ed. Martin Heidegger: Critical Assessments, vol. 4 (London and New York: Routledge, 1992), 33-77; Richard Wolin, "French Heidegger Wars," in Wolin, ed., The Heidegger Controversy: A Critical Reader (Cambridge: MIT Press, 1993), henceforth abbreviated to FHW; Dominique Janicaud, Heidegger en France (Paris: Albin Michel, 2001), (henceforth abbreviated to HF) vol. 1, ch. 10; Steven Ungar, "Revising Martin Heidegger," in Scandal and Aftereffect: Blanchot and France since 1930 (Minneapolis: U. Minnesota Press, 1995); scattered remarks in Henri Meschonnic, Le Langage Heidegger (Paris: PUF, 1990); Pierre Joris, "Heidegger, France, Politics, The University," http://wings.buffalo.edu/epc/authors/joris/Heideggerfascism.htm, last accessed May 29, 2001; Philip R. Wood, "Democracy' and "Totalitarianism' in Contemporary French Thought," in Jean-Joseph Goux and Philip R. Wood, Terror and Consensus (Stanford: Stanford UP, 1998), 75-103; idem, "French Thought Under Mitterand," Contemporary French Civilization 15:2 (Summer/ Fall 1991), 244-67. See also Anson Rabinbach, "Heidegger's 'Letter on Humanism' as 'Text and Event," in In the Shadow of Catastrophe: German Intellectuals Between Apocalypse and Enlightenment (Berkeley: Univ. of California Press, 1997), 97-128.

${ }^{4}$ This essay has, at least in part, been conceived as a counter-argument to existing accounts, though I do not go to lengths in discussing them.

5 The term ange (from the Greek aggelos_-"“celui qui transmet, à titre exceptionnel, la parole absolue") is Jean-Paul Aron's. See his Les modernes (Paris: Gallimard, 1984), 114.

${ }^{6}$ Annie Cohen-Solal, Sartre: A Life (New York: Pantheon, 1987), 119. Christian Delacampagne, A History of Philosophy in the 20th Century (Baltimore: Johns Hopkins University Press, 1999), 155. 


\section{STEFANOS GEROULANOS}

${ }^{7}$ Luc Ferry and Alain Renaut, Heidegger et les modernes, 35-6; henceforth abbreviated to HM. See also Alain Badiou, Manifeste pour la Philosophie (Paris: Seuil, 1989), ch. 2.

${ }^{8}$ Victor Farias, Heidegger et le Nazisme (Paris: Verdier, 1987). Henceforth abbreviated to VF.

${ }^{9}$ Sunil Khilnani, Arguing Revolution: Intellectual Left in Postwar France (London: Yale UP, 1993), ch. 5. Mark Lilla, "Legitimacy of the Liberal Age," New French Thought (Princeton: Princeton University Press, 1994), 14.

10 Zeev Sternhell, "Paperback Edition Preface," Neither Right nor Left (Princeton: Princeton University Press, 1996).

${ }^{11}$ Michel Haar, ed., Cahier de l'Herne: Martin Heidegger (Paris: L'Herne, 1983).

${ }^{12}$ Beaufret, Dialogue avec Heidegger, vol. 4, 77.

${ }^{13}$ In 1951, Birault wrote that he considered Beaufret's "Martin Heidegger et le Problème de la Vérité" "a masterful text on the master's thought." Henri Birault, "Existence et vérité d'après Heidegger," Revue de la Métaphysique et de Morale 56 (Jan-Mar 1951), 38-9. Birault's split is also attested to in HF 2:239.

${ }^{14}$ Magazine Littéraire 235 (Nov 1986), 56.

${ }^{15}$ Heidegger: Questions Ouvertes (Paris: C.I.P.-Osiris, 1988). Conference organised by the CIP on March 12-14, 1987. Giorgio Agamben had been close to the French Heideggerian group as well, and had attended some of the seminars at Le Thor. See François Fédier, Soixante-Deux Photographies de Martin Heidegger (Paris: Gallimard, 1999), ph. 31 and 50.

${ }^{16}$ Beaufret singled out Renaut (misleadingly and rather self-servingly) as the only student close to him who had come to reject his interpretation of Heidegger. Alain Renaut, "La Fin de Heidegger et la Tâche de la Philosophie," Les Etudes Philosophiques, (1977:4); Beaufret, "A propos de 'Questions IV' de Heidegger," in Les Etudes Philosophiques (1978:2), reprinted in Dialogue avec Heidegger IV (Paris: Minuit [Arguments], 1985), 81.

${ }^{17}$ In the 1940s, Beaufret published on Heidegger (and the first translation of Heidegger's own Letter on Humanism) in left-wing reviews emerging from the resistance such as Confluences and Fontaine. As for the later distance from intellectuals, see the interview with Emm. Martineau, Magazine Littéraire (222, Oct.1985). See also HF 1:213, 253; and the interview with Jacques Derrida, HF 2:96-101. Axelos calls Beaufret's later political judgment "a bit delirious" (HF 2:17).

${ }^{18}$ Martin Heidegger, Etre et Temps, trans. François Vézin (Paris: Gallimard, 1986).

${ }^{19}$ For an inclusive treatment of that debate, see HF vol. 1, ch. 9, esp. $317-34$

${ }^{20}$ Martin Heidegger, Etre et Temps, trans. Emm. Martineau (Paris: Authentica, 1985).

${ }^{21}$ Beaufret placed him among favored pupils in "A propos de 'Questions IV,'” 81.

${ }^{22}$ A compilation of documents and essays were published in Magazine Littéraire, 235 (Nov. 1986), 16-56.

${ }^{23}$ In the past (and as often happens with Heidegger translations elsewhere as well), Beaufret and Fédier had often been forced to defend their 


\section{SLAUGHTERBENCH OF HUMANISMS}

translation choices. See Jean Beaufret, "A propos de 'Questions IV' de Heidegger" and Fédier's response to Faye in Critique, 242 (Jul 1967), 672-86.

${ }^{24}$ François Vezin, "L'Horizon de la traduction," Magazine Littéraire (235, Nov 86), 33.

${ }^{25}$ See Le Monde, Dec. 12, 1986, and Jan. 16, 1987, 31; Libération, Mar. 12, 1987; L'Evenement du Jeudi, Jan. 22-28, 1987; L'Express, Jan. 16-22, 1987 et al. For a database of these attacks, see HF 1: esp. 326.

26 "Karl Marx et Heidegger," excerpted in France-Observateur (May 28, 1959), in full in Kostas Axelos, Arguments d'une Recherche (Paris: Minuit, 1969), 93-107.

\section{Littéraire (500), 4.}

${ }^{27}$ François Châtelet, "Qu'est-ce que la philosophie?” La Quinzaine

${ }^{28}$ For a treatment of Derrida's position in the Heidegger reception, see HF 1 ch.6, 2: 89-126. Among the more recent accounts of the influence of Heidegger on Derrida, see especially Paola Marrati, Genesis and Trace: Derrida Reading Husserl and Heidegger (Stanford: Stanford University Press, 2005).

${ }^{29}$ The essay "Sexual Difference, Ontological Difference" first appeared in the 1983 Cahier de L'Herne. It has been republished in Jacques Derrida, Heidegger et la Question: De L'Esprit et Autres Essais (Paris: Flammarion, 1990). Derrida had already expressed doubts regarding the sexual (and other) politics of Dasein in the 1981 exchange "Choreographies," reprinted in Points... (Stanford: Stanford UP, 1995), 103-5.

${ }^{30}$ Derrida, Heidegger et la Question, 169-172. The essay is far too careful with regard to Heidegger to be taken as a Heideggerian contribution, as Rockmore argues in Heidegger and French Philosophy, 140.

${ }^{31}$ Pierre Bourdieu, "L'Ontologie politique de Martin Heidegger," Actes de la recherche en sciences sociales (1975: 5-6). Extended and republished in 1988 (Paris: Minuit, 1988).

${ }^{32}$ Bourdieu, The Political Ontology of Martin Heidegger (Stanford: Stanford University Press, 1991), 15. For a critique of Bourdieu, see Hans Sluga, Heidegger's Crisis (Cambridge: Harvard University Press, 1993), 247-8.

${ }^{33}$ Les Temps modernes 14, (Nov 1946). Translated in Wolin, ed. The Heidegger Controversy., 167-185.

${ }^{34}$ Bourdieu, The Political Ontology of Martin Heidegger, 5-6, 101-5.

${ }^{35}$ At stake in the following quick description is not Levinas' thought and debt but the political tenor of his critique.

${ }^{36}$ Various readings of Levinas have focused on this point. See Alphonso Lingis' introduction to Levinas' Totality and Infinity (Pittsburgh: Duquesne UP, 1969), 11-13. Henceforth abbreviated to TI.

${ }^{37}$ Levinas, De l'evasion, ed. Jacques Rolland (Montpellier: Fata Morgana, 1982), translated as On Escape by Bettina Bergo (Stanford: Stanford University Press, 2003), henceforth abbreviated to OE. De l'existence à l'existant (Paris: Vrin, 1978). Autrement qu'être ou au-delà de l'essence (The Hague: Nijhoff, 1974).

${ }^{38}$ Levinas, Humanisme de l'autre homme (Montpellier: Fata Morgana, 1972), 93-112; translated as Humanism of the Other by Nidra Poller (Chicago: University of Illinois Press, 2004).

${ }^{39}$ In 1953, Gabriel Marcel also wrote and presented a radio-play, along the same lines, that apparently upset Heidegger and was in part 


\section{STEFANOS GEROULANOS}

responsible for the poor outcome of his only face-to-face meeting with Sartre; cited in HF 1:137.

${ }^{40}$ Levinas, Nov. 7, 1975 lecture in Dieu, la mort et le temps (Paris: Grasset [Figures], 1993), 16. See the English translation as God, Death and Time, trans. Bettina Bergo (Stanford: Stanford University Press, 2000), 8, trans. modified.

${ }^{41}$ A lot of sources can be used to point to the myths of heroic Greece-a most useful critical 1989 film concerning 1980s perceptions of Greece (largely in France itself) is Chris Marker's L'Héritage de la chouette (The Owl's Legacy [Attica Productions/Onassis Foundation], 1989)

${ }^{42}$ Roudinesco's criticism is cited in Derrida and Roudinesco, De quoi demain... (Paris: Fayard, 2001), 13; translated as Jacques Derrida and Elisabeth Roudinesco, For What Tomorrow: A Dialogue trans. Jeff Fort, (Stanford: Stanford University Press, 2004).

${ }^{43}$ Heidegger, Gesamtausgabe, vol. 15, 276, italics mine. Also cited in Safranski, Martin Heidegger, 404. The Thor seminars have recently appeared in English as Four Seminars: Le Thor 1966, 1968, 1969, Zabringen 1973 (Bloomington: Indiana University Press, 2003).

${ }^{44}$ Cornelius Castoriadis, World in Fragments, trans. D.A. Curtis (Stanford: Stanford University Press [Meridian], 1997). Claude Lefort, Essais sur le Politique (Paris: Seuil, 1986).

${ }^{45}$ Lacoue-Labarthe, "La Transcendance fini ${ }^{\mathrm{e}}$. dans la politique," Rejouer le politique (Paris: Galilée, 1982).

${ }^{46}$ Perhaps the most striking dimension of this non-conviction is the lack of attention accorded to the work of Kostas Axelos, whose attention to "planetary thought" and revisiting of Heidegger's Gestell in explicit connection to Marx remain unknown, despite rising theoretical concern over precisely these themes. See his Marx, Penseur de la Technique (Paris: Minuit, 1962), and Vers La Pensée Planetaire (Paris: Minuit, 1964).

${ }^{47}$ André Glucksmann, Les Maîtres Penseurs (Paris: B. Grasset, 1977).

${ }^{48}$ Richard Kearney and Joseph S. O'Leary, Heidegger et la Question de Dieu (Paris: Grasset [Figures], 1980). It should be noted that Lévy has remained more balanced toward Heidegger than other Nouveaux Philosophes. See his ambivalently positive approach in Le Siècle de Sartre (Paris: Grasset, 2000), pt. 1, ch. 5 .

${ }^{49}$ Derrida, Margins of Philosophy, tr. A. Bass (Chicago: Univ. of Chicago Press, 1982), 108-36.

${ }^{50}$ Note Kojève's comments on the lack of metaphysical difference between America and Russia, cited in Stanley Rosen, "Kojève's Paris: A Mémoir," Parallax 4 (February 1997), 6. See Lilla, "The Legitimacy of the Liberal Age," 6-15, for a criticism of antihumanism as indistinguishable from illiberalism.

${ }^{51}$ See Foucault's usage of Heidegger's usage of the fore-structures of interpretation as structures of historical analysis in his Archaeology of Knowledge (New York: Pantheon, 1976). A reading of structuralist antihumanism can be found in Richard Wolin, "Antihumanism and the Discourse of French Postwar Theory," Labyrinths: Explorations in the Critical History of Ideas (Amherst: University of Massachusetts Press., 1995), 175209. 


\section{SLAUGHTERBENCH OF HUMANISMS}

${ }^{52}$ For a recent analysis of Solzhenitsyn's book and its connections to the Nouveaux Philosophes mouvement, see Kristin Ross, May ' 68 and its Afterlives (Chicago: University of Chicago Press, 2002), 170-2.

${ }^{53}$ François Furet, Penser la Révolution Française (Paris, 1978). Also see Khilnani, Arguing Revolution, ch. 6.

${ }^{54}$ Khilnani, Arguing Revolution, 183-5 and ch. 5.

${ }^{55}$ Lyotard contrasts French Neo-Humanism qua ethicopolitical humanism to the humanisms of Davidson, Rorty, Habermas, Rawls, et. al., in his The Inbuman: Reflections on Time (Stanford: Stanford UP, 1991), 1. Against the simplistic reading of Derrida as an anti-Enlightenment thinker comes Derrida's own D'un ton apocalyptique adopté naguerre en philosophie (Paris: Galilée, 1983), trans. by John Leavey Jr, in Peter Fenves, ed. Raising the Tone of Philosophy (Baltimore: Johns Hopkins University Press, 1993). See also Jean-Luc Nancy, L'oubli de la philosophie (Paris: Galilée, 1986).

${ }^{56}$ Luc Ferry, From the Rights of Man to the Republican Idea, 24.

${ }^{57}$ Even Castoriadis and Marcel Gauchet have also cautioned against taking "human rights" as a politics in and of itself. Ferry cites Gauchet and Lefort to that extent in From the Rights of Man to the Republican Idea, 2,4.

${ }^{58}$ Pierre Manent, The City of Man (Princeton: Princeton UP, 1998), esp. ch. 1-2.

${ }^{59}$ Gilles Lipovetsky, L’Ere du Vide: Essais sur l'individualisme contemporain (Paris: Gallimard, 1983).

${ }^{60}$ Luc Ferry and Alain Renaut, La Pensée 68: essai sur l'anti-bumanisme contemporain (Paris: Gallimard, 1985). See also Lilla, "The Legitimacy of the Liberal Age," 19.

${ }^{61}$ One could then suggest that Ferry \& Renaut come somewhat close to Derrida's "Ends of Man"- though for somewhat different reasons. They saw antihumanism's presumed rejection of ethics and human values as the danger in 60s thought; Derrida saw the danger in 60s thought as being its pretense to antihumanism, insisting that the latter could claim little philosophical superiority against ideologically-flawed humanisms.

${ }^{62}$ Ferry and Renaut, French Philosophy of the Sixties (Amherst: University of Massachusetts Press, 1990), 12.

${ }^{63}$ Ferry and Renaut, French Philosophy of the Sixties, ch. 1 (esp. 13). The parallel to Derrida's "Ends of Man" treatment of 60s Heideggerianism and Nietzscheanism ends at these rejections and the call for simplicity.

${ }^{64}$ Luc Ferry and Alain Renaut, 68-86: Itineraires de l'individu (Paris: Gallimard [Le Monde Actuel], 1987). Their surprising dedication to Cornelius Castoriadis came in part for his having transformed his thinking during the $70 \mathrm{~s}$ in favour of an anarchic democratic imaginary and in part because $68 / 86$ was a response to his rejection of their Pensée 68. For Castoriadis' criticism, which aptly pointed out that structuralism, Derrida, Foucault, and Heideggerianism had nothing to do with May 1968, see "Movements of the Sixties" in World in Frangments, 47-57 and "The Diversionists" in Political and Social Writings 3: Recommencing the Revolution: From Socialism to the Autonomous Society, (Minneapolis: University of Minnesota Press, 1993), 272-77.

${ }^{65}$ Gilles Lipovetsky, L'Ere du vide: essais sur l'individualisme contemporain (Paris: Gallimard, 1983). As Castoriadis himself pointed out (to criticize Ferry 


\section{STEFANOS GEROULANOS}

and Renaut), Ferry and Renaut were basically reiterating many of Lipovetsky's theses (Castoriadis, "The Movements of the Sixties," 47).

${ }^{66}$ André Glucksmann, Descartes, c'est la France (Paris: Flammarion, 1987).

${ }^{67}$ Jean-Michel Palmier, "Heidegger et le national-socialisme," in Martin Heidegger: Cabier de l'Herne, 350-1.

${ }^{68}$ Karl Löwith, Mein Leben in Deutschland vor und nach 1933: ein Bericht (Stuttgart: J. B. Metzler, 1986); published in France as $\mathrm{Ma}$ Vie en Allemagne avant et après 1933 (Paris: Hachette, 1988).

${ }^{69}$ See for example, Maurice Blanchot, "Penser l'apocalypse," Le Nouvel Observateur, Jan. 22-28, 1988, 79.

${ }^{70}$ Philippe Lacoue-Labarthe, L'Imitation des modernes: Typographies II (Paris: Galilée, 1986), e.g. 123.

38.

${ }^{71}$ Palmier, "Heidegger en France," Magazine Littéraire 235 (Nov 1986),

${ }^{72}$ Alain Boutot, Heidegger et Platon: le problème du nibilisme (Paris: PUF); Jacques Derrida, De l'Esprit: Heidegger et la question (Paris: Galilée); Victor Farias, Heidegger et le Naqisme (Paris:Verdier). Luc Ferry et Alain Renaut, 68-86:Itinéraires de l'individu (Paris: Gallimard); Michael Gelven, 'Être et temps' de Heidegger: un commentaire littéral (Brussels/Paris: Mardaga); Jean Greisch, Parole heureuse: Martin Heidegger entre les choses et les mots (Paris: Beauchesue); Jean Grondin, Le Tournant dans la pensée de Martin Heidegger (Paris: PUF); Michel Haar, Le Chant de la terre: Heidegger et les assisses de l'histoire de l'etre (Paris: L'Herne); Philippe LacoueLabarthe, La Fiction du politique: Heidegger, l'art et la politique (Paris: Bourgois); Ulrika M. Lindblad, L'intelligibilité de l'Etre selon Saint Thomas d'Aquin et selon Martin Heidegger (Paris: Lang); Jean-Michel Palmier, Situation de Georg Trakl (Paris: Belfond); Richard Regrald, Heidegger et le problème du néant (Dordrecht: Nijhoff); Elisabeth Rigel, Du Strass sur un tombeau (Mauvezin: Transeuropress); George Steiner, Martin Heidegger (Paris: Flammarion); Giovanni Vattimo, La Fin de la modernité: nibilisme et herméneutique dans la culture post-moderne (Paris: Seuil).

${ }^{73}$ Fédier, Glucksmann, Faye and George Steiner went on Océaniques, FR3, Dec. 7, 1987 (HF 1: 355n.21).

${ }^{74}$ Janicaud correctly points to a neurotic character in the reaction to the Farias book, a character that various commentators on French media debates have over the course of time pointed out (HF 1:383).

${ }^{75}$ Pierre Aubenque, "Encore Heidegger et le Nazisme," Le Debat 48 (Jan-Feb 1988), 113.

${ }^{76}$ “M. Heidegger, Professeur de PhiloNazie" in L'Evenement du Jeudi, Oct. 29, 1987, 124.

77 “Heil Heidegger!" in Libération, Oct. 16, 1987, 40-1. The images were first published in Schneeberger's Nachlese zu Heidegger in 1961 but were largely unavailable in France as a consequence of François Fédier's 1966-8 articles in Critique, which largely succeeded in controlling the possible damage from the publication of such images and many of Heidegger's most virulent texts.

${ }^{78}$ The concerns of Liberation were echoed in articles in most other newspapers. Concurrent publications were "Heidegger, militant et penseur nazi" in Le Matin, Oct. 15, 1987, 16; "Heidegger soupçonné” in La Croix, 


\section{SLAUGHTERBENCH OF HUMANISMS}

Oct. 17, 1989, 11; Roger Pol-Droit, "Heidegger était-il Nazi?” in Le Monde, Oct. $14,1987$.

79 "Interview de Christian Jambet: 'Martin Heidegger: achèvement de la métaphysique et politique d'extermination," in Art Press 117 (1987), 9. 1987,2

${ }^{80}$ Roger Pol-Droit, "Heidegger était-il Nazi?" in Le Monde, Oct. 14,

${ }^{81}$ In addition to the publications on/of Heidegger in Arguments and Axelos' Marx, penseur de la technique, and Vers la pensée planetaire, see Janicaud's interviews with Axelos and Edgar Morin in HF 2: esp. 231-2.

${ }^{82}$ Louis Althusser, Lénine et la philosophie (Paris: Maspero, 1969), 15.

${ }^{83}$ Hyppolite's essay, "Ontologie et Phenomenologie chez Heidegger" appeared in Etudes Philosophiques (1954:3), 307-14. Alexandre Kojève, Introduction à la Lécture de Hegel (Paris: Gallimard, 1947); Weil, "Le Cas Heidegger" in Les Temps modernes 22 (Jul 1947), and Michael S. Roth, Knowing and History: Appropriations of Hegel in Twentieth Century France (Ithaca: Cornell University Press, 1988).

${ }^{84}$ Guido Schneeberger, Nachlese zu Heidegger: Dokumente zu seinem Leben und Denken (Bern, 1962). See the early, partial American publication of the Nachlese as German Existentialism: Martin Heidegger, trans. Dagobert Runes (New York: Philosophical Library, 1965)—whose cover bears the title and a swastika. Ott's work prior to his 1988 biography of Heidegger (Martin Heidegger: Unterwegs zu seiner Biographie (Frankfurt: Campus, 1988)) is cited by Wolin in FHW 297n.6, 303.

${ }^{85}$ Heidegger, "Le Rectorat 1933-4," Écrits politiques 1933-1966 (Paris: Gallimard, 1995), 235.

${ }^{86}$ It is unclear what, if any, influence was exerted by Jean-Michel Palmier's Les Ecrits Politiques de Heidegger (Paris: L'Herne, 1968). Palmier discussed Heidegger's texts quite sympathetically, arguing that they had never been closely read, placing Heidegger somewhere between Rilke and Jünger, and notably (and significantly) by contrasting Heidegger to Ernst Krieck (95100, 297-8).

${ }^{87}$ Farias, Heidegger et le Nazisme, esp. 39-55, 291-301.

${ }^{88}$ In Heidegger et le Nazisme, 39-55 and 291-301 (28 pages in all) are devoted to the texts on Abraham à Santa Clara and 67-76 (10 pages in total) to Sein und Zeit. See also the conclusion, 305.

${ }^{89}$ François Fédier, "Trois Attaques Contre Heidegger," in Critique 234 (Nov 1966), 883-904.

90 "M. Heidegger, professeur de PhiloNazie" in L'Evenement du Jeudi (Oct. 29, 1987), 124-25, is a good example of what Derrida referred to as a desire to burn Heidegger: "Victor Farias accumule les faits au fil des pages. Sans passion. Sans lyrisme. Comme un chirurgien effectuant une autopsie. Ce faisant il suscite bien des questions dans l'esprit de son lecteur. D'autant plus vives que ce lecteur aura peut-ëtre terminé dans le même temps une autre lecture: celle du nouvel ouvrage de Jacques Derrida, justement consacré à Heidegger, De L'Esprit, Heidegger et la Question. Parce que la seule question qui demeure aujourd'bui est de savoir si l'on peut encore lire Heidegger." (L'Evenement du Jeudi, Oct. 29, 1987, 125). Other particularly anti-Heidegger reviews: "Heil Heidegger!" in Libération, Oct. 16, 1987, 40-1. See also the article on the translation of George Steiner's Martin Heidegger, in Libération, Oct. 20, 1987. "Heidegger, militant et penseur nazi" in Le Matin, Oct. 15, 1987, 16. "Mister 


\section{STEFANOS GEROULANOS}

Hyde philosophe" in Le Monde des Livres, Oct. 30, 1987. Alain Renaut, "La 'Déviation Heideggerienne,"' Le Débat 48 (Jan-Feb1988), 172-5. Hugo Ott, "Chemins et fourvoiements," Le Débat 49 (Mar-Apr 1988), 185-9. GeorgesArthur Goldschmidt, "D’une abjection à l'autre," Le Débat 49: 191-2; idem, "Heidegger: l'Allemand et le ressentiment: réponse à Alain Finkielkraut," Le Monde, Jan.13, 1988. Le Soir, Nov. 12, 1987. Quotidien de Paris, Dec. 22, 1987.

91 "Heidegger: L'Enfer des Philosophes" in Le Nouvel Observateur, Nov. 6-12, 1987, 170-4, translated as "Heidegger, the Philosophers' Hell," in Points..., 181-2. Henceforth abbreviated to HPH.

${ }^{92}$ Derrida, "Comment Donner Raison?" in Points... (Stanford: Stanford University Press [Meridian], 1995), 194.

${ }^{93}$ For Derrida's similar dismissal of Pensée 68 ("un livre nul mais symptomatique. Interessant parce que symptomatique!”), see Derrida/ Roudinesco, De quoi demain..., 29-36; citation: 31.

${ }^{94}$ Farias, "Pas d'Accord Avec Jacques Derrida," in Le Nouvel Observateur, Nov. 27-Dec. 3, 1987, 4.

95 “La Réponse de Jacques Derrida," Le Nowvel Observateur, Nov. 27Dec. 3, 1987, 4.

${ }^{96}$ Derrida acknowledges as much in his interview with Dominique Janicaud (HF 2:107).

97 "L'acharnement des médiocres contre Heidegger, je l'ai vu à l'oeuvre toute ma vie." François Fédier, "Une grosse bêtise," in Le Nouvel Observateur (Jan. 22-28, 1988), 84. Crétella, who published a short note ("Une inepte perfidie") in Le Monde des Livres (Oct. 30, 1987), 19, and a longer article in Le Débat 48 (Jan-Feb 1988), 124-9, repeated exactly this accusation. For avid and largely uncritical defenses of Heidegger, see Le Débat 48 (Jan-Feb 1988), 114-171; Le Monde des Livres (Oct. 30, 1987), 19; Le Monde, (Jan. 5, 1988), 2; Roger-Pol Droit, "Heidegger: la parole à la défense" in Le Monde (May 27, 1988), 2; and Le Messager Européen (2, 1988), 151-227. Also, Fédier's book-length refutation of Farias, Heidegger: Anatomie d'un scandale (Paris: Laffont, 1987).

140.

${ }^{98}$ Aubenque, "Encore Heidegger et le Nazisme," 113-23.

${ }^{99}$ François Fédier, 'L'intention de nuire,’ Le Débat48 (Jan-Feb 1988),

${ }^{100}$ Fédier, "L'intention de nuire," 136. See also FHW 297n.8. It has recently been argued that Fedier's own publication practices were not exactly pillars of publication ethics. See HF 2: 99,262-66.

${ }^{101}$ Pierre Joris has shown that Fédier's argument against Farias is not without its own exaggerations and factual errors. See Pierre Joris, "Heidegger, France, Politics, The University."

${ }^{102}$ Fédier, Heidegger: anatomie d'un scandale, 29-31, 47. As though he is participating in a trial against defamation, and without recourse to almost any evidence, Fédier interestingly “asserts” Farias' malign intentions in p. 31 (italics his): "J'affirme que cette accusation est une calomnie."

${ }^{103}$ Libération, Jan .7, 1988. FHW 281-2, 298n.20. Annales de l'Histoire Revisioniste 3 (Fall-Winter 1987). Meschonnic, Le L angage Heidegger, 23n.3. There is no indication in the letters that Beaufret's "revisionism" was of Faurisson's intensity; both Fédier and Meschonnic think the publication of the letters exaggerated. 


\section{SLAUGHTERBENCH OF HUMANISMS}

${ }^{104}$ Interview with Emmanuel Martineau, in Magazine Littéraire 222 (Oct 1985).

${ }^{105} \mathrm{HF}$ 1:213, 253; also the interview with Jacques Derrida in HF 2:96-101.

${ }^{106}$ L'Endurance de la Pensée: Pour Saluer Jean Beaufret (Paris: Plon, 1968). "Ousia et Gramme" was republished in Derrida, Marges de la philosophie (Paris: Minuit, 1972). See Margins of Philosophy, 29-68.

${ }^{107}$ In a later letter to Hugo Ott, Fédier defended Beaufret in a selfconsciously apologetic tone, interestingly making rather little effort to affirm that Beaufret's politics stood outside the horizons of revisionism. The letter is republished in François Fédier, Regarder voir (Paris: Belles Lettres [Archimbaud], 1995), 245-52. abbreviated to FP.

108 Philippe Lacoue-Labarthe, La Fiction du politique, henceforth

${ }^{109}$ Jacques Derrida, De l'Esprit: Heidegger et la question (Paris: Galilée, 1987); translated as Of Spirit: Heidegger and the Question (Chicago: University of Chicago Press, 1987). Henceforth abbreviated to OS.

${ }^{110}$ Both had been completed long before the publication of Heidegger et le Nazisme. Derrida first gave Of Spirit as a lecture on March 14, 1987, at the conference Heidegger, questions ouvertes. In the book he points to the long development of his argument. OS 8,117n.3. La Fiction du politique (an excerpt from which Lacoue-Labarthe gave at the same conference) was LacoueLabarthe's dissertation (on the basis of published work), which he had defended well before October. Moreover, both Derrida and Lacoue-Labarthe have taken pains to point out that they did not plan these texts "to stake out a position on the philosophical implications" of "the troubling revelations from the other side of the Rhine" (FHW 284). Nonetheless, It would be silly to suggest that these "troubling revelations" were entirely unrelated to the Derrida/Lacoue-Labarthe positions-though I would not follow Wolin into seeing a certain casual relationship there.

${ }^{111}$ The emphasis on Blanchot and Levinas' influence as constituting the basis of a "third wave" of Heidegger readership is a major claim of Ethan Kleinberg, Generation Existential: Heidegger's Philosophy in France, 19271961 (Ithaca: Cornell University Press, 2005)

${ }^{112}$ Dark Continent is Mark Mazower's designation of $20^{\text {th }}$ century Europe in his synonymous book (London: Random House, 1998).

${ }^{113}$ OS 109-11. Derrida repeats his mushroom metaphor in the interview for Le Nouvel Observateur: "Heidegger, The Philosopher's Hell", 184.

${ }^{114}$ Derrida concludes the book without making it clear that Heidegger has succeeded. The last word goes to Heidegger's imaginary Catholic interlocutors whom Derrida carefully presents as unconvinced. For this reason, I would like to withhold from agreeing to the classical argument that has Heidegger as having finally succeeded in overcoming the metaphysics of spirit at that point. Interestingly, Derrida makes nothing of the parallel 1953 republication of Heidegger's Introduction to Metaphysics-either to suggest that that republication taints the novelty of the Trakl text concerning spirit and ashes, or to use the Trakl essay to suggest a move, in Heidegger, beyond the troubling past with "spirit."

${ }^{115}$ Jacques Derrida, "Geschlecht I: différence sexuelle, différence ontologique" and "Geschlecht II: la main de Heidegger," in his Heidegger et la 


\section{STEFANOS GEROULANOS}

question (Paris: Flammarion, 1990); and "L'oreil de Heidegger: philopolemologie (Geschlecht IV)" in Politiques de l'amitie (Paris: Galilée, 1994). All three essays point to failings in Heidegger, and function as earmarks toward a different understanding of his work, an understanding which argues failures in his understanding of the subject. All of them, moreover, are concerned with a deconstruction, influenced by Levinas (and, of course, Sartre), of Heidegger's failure to adequately consider "the Other" in his thought. In his Heidegger and French Philosophy, Rockmore fails to penetrate the first essay; his writing on Derrida should not be considered reliable in this context.

${ }^{116}$ In "Eating Well." Derrida insists that Dasein remains the ground for a dismantling of subjectivity - in his words, of "the who" (266). At the end of the essay Derrida speaks also of "Heidegger's silence" after 1945.

${ }^{117}$ Derrida is particularly concerned with this motif. He discusses Helvetius' De l'Esprit and its burning by the Catholic Church (OS 115n.4), implicitly comparing the event to the fictional dialogue between Heidegger and Christian humanists which he sets up at the end of the book. That Derrida points toward the humanists of the traditions he has opposed, especially toward his contemporaries, is clear. However, this does not mean that Derrida takes a Heideggerian or even a "pro-Heidegger" stance in the debate. Though Derrida expressly argues against the attempts to "burn [Heidegger's] work," in the book he gives the last word to the imaginary theologians in an ending which can hardly be said to favour Heidegger. See also the review of De l'Esprit in Critique ("Le Philosophe et son Double," Critique 491 (Apr 1988), 260.

${ }_{118}$ Regarding Husserl, see also Gérard Granel, Écrits Logiques et Politiques (Paris: Galilée, 1990), 48.

${ }^{119}$ Philippe Lacoue-Labarthe, La Poésie comme experience (Paris: Christian Bourgois, 1986). Lacoue-Labarthe, "La Transcendance fini" / dans la politique," and "Poétique et Politique" (as well as "Histoire et mimésis" and "L'Antagonisme," where Lacoue-Labarthe fingers Heidegger for denigrating mimesis to inauthenticity and utilizing "thought" for transitory political needs) in L'Imitation des modernes.

${ }^{120}$ Wolin's argument (seconded by Rockmore) that, in LacoueLabarthe's account, "the post-1935 Heidegger emerges virtually unscathed" (FHW 284) is unfounded. Unlike Wolin, I would distinguish Lacoue-Labarthe from Derrida on the issue of rescuing the later Heidegger.

${ }^{121}$ For the Cérisy-La-Salle conference, see HF 1:147-63, but also Aron, Les modernes, 114-25; Eryck de Rubercy et al, Douze questions posées à Jean Beaufret (Paris: Aubier, 1983), 86; Beaufret, "En France," in Erinnerung an Martin Heidegger (Pfullingen: Neske, 1977); Elisabeth Roudinesco, Jacques Lacan (New York: Columbia University Press, 1997). Janicaud is most careful and extensive, and tones down the arguments somewhat.

${ }^{122}$ FP 26. Also: "To be or to call oneself a 'Heideggerian' signifies nothing, nothing more than to be or to call oneself an 'anti-Heideggerian"” (FP 25). Lacoue-Labarthe again attacks Fédier's translations for their "muting effect" on Heidegger's radical tone (FP 85n.3).

${ }^{123}$ See, for example, Adorno's criticism of "neutral politics" in Minima Moralia: Reflections from Damaged Life (London: New Left Books, 1974), §13.

${ }^{124} \mathrm{FP} 91$. The theme is elaborated in ch. 7,8 .

${ }^{125}$ At times Lacoue-Labarthe identifies National Aestheticism with National Socialism, at times he delimits it to invoke a more general attitude 


\section{SLAUGHTERBENCH OF HUMANISMS}

that he considers foundational to Nazism.

${ }^{126}$ Rabinbach, In the Shadow of Catastrophe, 125.

${ }^{127}$ FP 58-9. For "archifascism", and "Nazism," see the terminological reflections in ch. 10, esp. 159-160.

${ }^{128}$ It is not as easy — as Ferry and Renaut, and, following them, Rockmore, claim - to place Lacoue-Labarthe solidly with Beaufret's partisans, or even with a group of "dissident Heideggerians" following Derrida. Not only is this ultimately a refusal of deconstruction and its place and politics in 1970s and 1980s French thought (not to mention a paradoxical and-at once historically and philosophically wrong-Heideggerian domestication of deconstruction), but moreover Lacoue-Labarthe derided many of Heidegger's claims to such an extent that he can hardly be simply placed under an umbrella built by his personal and philosophical proximity to Derrida. He can certainly not be placed under Beaufret's wing, while his opposition to the mere idea of a "Heideggerianism" is indicative of his understanding of the "use" of Heidegger as partial groundwork for further thought.

${ }^{129}$ Jean-François Lyotard, Heidegger and "The Jews," (Minneapolis: Univ. Minnesota Pr., 1990).

${ }^{130}$ Lyotard, Heidegger and "The Jews," 85-9. For a useful reading of Lyotard, see FHW 291-4.

${ }^{131}$ Lyotard, Heidegger and "The Jews," 94.

${ }^{132}$ Le Nowvel Observateur, (Jan.22-8, 1988), 75-84. Derrida, LacoueLabarthe, Hans-Georg Gadamer, Levinas, Blanchot and Fédier all wrote for this issue - though only the latter five articles were published.

${ }^{133}$ Catherine David, "Heidegger et la pensée nazie," Le Nouvel Observateur, Jan.22-8, 1988, 76.

${ }^{134}$ Lacoue-Labarthe dedicated his book to Blanchot. Both Blanchot and Levinas praised Lacoue-Labarthe in their respective texts. Blanchot also thanked Levinas for helping him understand Sein und Zeit.

${ }^{135}$ Points..., 194. This theme runs through Lacoue-Labarthe's and Levinas' texts, as well as through Derrida's "Comment Donner Raison?" which was to be published with them (Points..., 469).

${ }^{136}$ A lecture by Mikkel Borch-Jacobsen at the Collège International de Philosophie in November 1987, ostensibly on Freud and Michel Henry (translated as "The Unconscious, Nonetheless," in his The Emotional Tie: Psychoanalysis, Mimesis and Affect [Stanford: Stanford UP, 1993]), provides another indication at once of the ambivalence toward Heidegger $(124-6,128)$ and defense of Derrida's critical engagement (129).

${ }^{137}$ Blanchot, in Le Nouvel Observateur, Jan. 22-8, 1988, 79. For Blanchot, who concerned himself decisively with this failure, see Ungar, Scandal and Aftereffect, 60-9. For Blanchot's attitude toward humanism, see his "L'Lathéisme et l'écriture, l'humanisme et le cri'" in L'Entretien Infini (Paris: Gallimard, 1969), 367-93.

${ }^{138}$ Ferry and Renaut repeatedly attempt to reduce Derrida's and Lacoue-Labarthe's stances to a position analogous to Heideggerian orthodoxy; this argument has been largely taken up by outsiders reflecting on the debate, notably Rockmore. As argued above, I disagree with the position that reduces the nuances in Derrida and Lacoue-Labarthe to a single stance, and especially with joining the two to the orthodox stance. 


\section{STEFANOS GEROULANOS}

${ }^{139}$ HM 13. François Dosse, History of Structuralism, vol. 2 (Minneapolis: University of Minnesota Press., 1997), 358.

${ }^{140}$ The book begins with a declaration of victory ("Intellectual History is decidedly not ungrateful." (9)), claiming that the time for polemics is over (11), despite the obvious polemical tone (especially as regards Derrida and Lacoue-Labarthe). Later, the book belligerently pairs Heidegger with an anti-Semitic worldview while acknowledging lack of evidence to support such a claim (58-59).

${ }^{141}$ See Alexander Nehamas's critique, "The Rescue of Humanism," New Republic, (Nov. 12 1990), 27-35.

142 Pierre Bourdieu, "Heidegger par Pierre Bourdieu," Libération, (Mar. 10, 1988), VII; trans. as "Back To History: An Interview" in Wolin, ed. Heidegger Controversy, 264-271.

143 "Derrida-Bourdieu débat," in Libération, (Mar. 19, 1988), 36. Bourdieu clearly sought to clear Derrida from the mess that the debate had degenerated into: hence his comments regarding Derrida's acceptance of Bourdieu's book and his comment that Derrida had been brought to a difficult position. Derrida's response, passionate and defensive as it was, can perhaps be explained by a desire "to be saved only on his own terms" and to be allowed to respond to and accept his debts on his own account.

${ }^{144}$ The last one was the Derrida-Bourdieu debate of March 19 in Libération. Earlier ones had included a debate between Alain Finkielkraut and Georges-Arthur Goldschmidt in Le Monde (Jan. 5 and Jan. 13, 1988). 481.

${ }^{145}$ Alain Badiou, Being and Event (New York: Continuum Press, 2006),

${ }^{146}$ The debate did not visibly trouble the appointment of Henri Birault, longtime Heidegger defender and a fairly orthodox reader at odds with Beaufret's circle, at Paris-IV in early 1988. Other Heideggerians, orthodox and not, also came to significant posts in the French university at the timelike Michel Haar at Paris-I, and Jean-François Courtine at Paris-IV and the Ecole Normale Supérieure.

${ }^{147}$ Frédéric de Towarnicki, A la rencontre de Heidegger (Paris: Gallimard, 1993); idem, Martin Heidegger: souvenirs et chroniques (Paris: Rivages, 1999). Roger Munier, Stele pour Heidegger (Paris: Arfuyen, 1992).

${ }^{148}$ François Fédier, Soixante-deux photographies de Martin Heidegger (Gallimard, Paris, 1999).

${ }^{149}$ Martin Heidegger, Écrits politiques 1933-1966, trans. François Fédier (Paris: Gallimard, 1995).

Écrits politiques.

${ }^{150}$ See his long "Revenir à plus de décence," the preface to Heidegger,

${ }^{151}$ Henri Meschonnic, Le Langage Heidegger (Paris: PUF, 1990). JeanPierre Faye, Le Piege (Paris: Balland, 1994).

${ }^{152}$ Meschonnic, Le Langage Heidegger, e.g. 383.

${ }^{153}$ See, for example, Arno Munster, "Heidegger nazi, la preuve par l'eugenisme," Libération, (June 9, 2001), 30-1 and the article in Le Monde, (June 15, 2001), x.

${ }^{154}$ Emmanuel Faye, Heidegger, l'introduction du nazisme dans la philosophie : Autour des séminaires inédits de 1933-1935 (Paris: Albin Michel, 2005).

${ }^{155}$ See the February 23, 2007 broadcast of the TV program Bibliothèque Médicis, which included a broad argument between Fédier and 


\section{SLAUGHTERBENCH OF HUMANISMS}

Faye (transcript: http:/ / skildy.blog.lemonde.fr/2008/02/03/transcription-dudebat-fayefedier-du-23-02-07-2/, last accessed 4/6/2008). Among the reactions to the debate, see Paul-François Paoli, "Quand le débat a lieu, Figaro Littéraire (Feb. 25, 2007).

${ }^{156}$ See http:/ / parolesdesjours.free.fr/scandale.htm

${ }^{157}$ François Fédier, et al. Heidegger à plus forte raison (Paris: Fayard, 2007).

${ }^{158}$ See the debates in Le Figaro littéraire (Sep. 28, 2006), Le Monde des livres (Sep. 29, 2007), L'Infini (Summer 2006).

${ }^{159}$ Emmanuel Faye, "Pour l'ouverture des Archives Heidegger," Le Monde (Jan. 5, 2006). Online publication at http://aps.sulb.uni-saarland.de/ theologie.geschichte/inhalt/2006/07.html

${ }^{160}$ Palmier, "Heidegger et le National-Socialisme," Magazine Littéraire 255 (Jun 1988), 89-93.

${ }^{161}$ Palmier remarks that while he is not convinced by LacoueLabarthe, the latter's account is "plausible." He finds himself more compelled by Bourdieu's and Lyotard's arguments, despite various reservations. 1990), 353.

${ }^{162}$ Jean-François Courtine, Heidegger et la phénoménologie (Paris: Vrin,

163 Dominique Janicaud, "Heidegger Nazi?" in France-Observateur (Dec. 12, 1963), 2.

${ }^{164}$ Janicaud, L’Ombre de Cette Pensée (Grenoble: Millon, 1990).

165 Derrida, Politiques de l'amitié. (Paris: Galilee, 1994), 343-419.

Derrida, Points..., 255-87.

77.

${ }^{166}$ Derrida, Aporias (Stanford: Stanford University Press [Meridian]), Jan. 27, 1988, 2.

${ }^{167}$ Jean Baudrillard, "Necrospective autour de Heidegger," Libération,

${ }^{168}$ François Dosse, Paul Ricoeur: les sens d'une vie, 425.

${ }^{169}$ His critique of neo-humanism predates the Heidegger affair and can be found in Jean-Luc Nancy, L'oubli de la philosophie (Paris: Galilée, 1986).

${ }^{170}$ The term is Tony Judt's; he applies it to neoliberalism in general.

See Judt, Past Imperfect: French Intellectuals, 1944-56 (Berkeley: University of California Press, 1992), see the conclusion, esp. 314. 